\title{
Involvement of Placental Growth Factor in Wallerian Degeneration
}

\author{
LINDA CHABALLE, ${ }^{1}$ PIERRE CLOSE,${ }^{2}$ MAXIME SEMPELS, ${ }^{1}$ STÉPHANIE DELSTANCHE, ${ }^{1}$ \\ JULIEN FANIELLE, ${ }^{1}$ LIEVE MOONS, ${ }^{3}$ PETER CARMELIET, ${ }^{4}$ JEAN SCHOENEN, ${ }^{1}$ \\ ALAIN CHARIOT, ${ }^{2}$ AND RACHELLE FRANZEN ${ }^{1 *}$ \\ ${ }^{1}$ GIGA Neurosciences, Axonal Regeneration and Cephalic Pain unit, University of Liege, Avenue de l'Hopital, Liege, Belgium \\ ${ }^{2}$ GIGA Signal Transduction, Laboratory of Medical Chemistry, University of Liege, Avenue de l'Hopital, Liege, Belgium \\ ${ }^{3}$ Laboratory of Neural Circuit Development and Regeneration, Zoological Institute KU Leuven, Naamsestraat, Leuven, Belgium \\ ${ }^{4}$ Vesalius Research Center, VIB, Leuven, Belgium and Vesalius Research Center, KU Leuven Herestraat, Leuven, Belgium
}

\section{KEY WORDS}

PNS injury; inflammation; Schwann cell; cytokine; NF-кB

\begin{abstract}
Wallerian degeneration (WD) is an inflammatory process of nerve degeneration, which occurs more rapidly in the peripheral nervous system compared with the central nervous system, resulting, respectively in successful and aborted axon regeneration. In the peripheral nervous system, Schwann cells (SCs) and macrophages, under the control of a network of cytokines and chemokines, represent the main cell types involved in this process. Within this network, the role of placental growth factor (PlGF) remains totally unknown. However, properties like monocyte activation/ attraction, ability to increase expression of pro-inflammatory molecules, as well as neuroprotective effects, make it a candidate likely implicated in this process. Also, nothing is described about the expression and localization of this molecule in the peripheral nervous system. To address these original questions, we decided to study PlGF expression under physiological and degenerative conditions and to explore its role in WD, using a model of sciatic nerve transection in wild-type and $P g f^{-1-}$ mice. Our data show dynamic changes of PlGF expression, from periaxonal in normal nerve to SCs $24 \mathrm{~h}$ postinjury, in parallel with a p65/ NF- $\kappa$ B recruitment on Pgf promoter. After injury, SC proliferation is reduced by $30 \%$ in absence of PlGF. Macrophage invasion is significantly delayed in $P g f^{-1-}$ mice compared with wild-type mice, which results in worse functional recovery. MCP-1 and proMMP-9 exhibit a 3 -fold reduction of their relative expressions in $P g f^{-1-}$ injured nerves, as demonstrated by cytokine array. In conclusion, this work originally describes PlGF as a novel member of the cytokine network of WD. $\odot 2010$ Wiley-Liss, Inc.
\end{abstract}

\section{INTRODUCTION}

Wallerian degeneration (WD) is the active process of degradation of the nerve segment distal to the lesion site. First described in 1850 (Waller, 1850), WD is critical for successful axonal regeneration and occurs more rapidly in the peripheral than in the central nervous system, where axonal regeneration fails (Lawson et al., 1994; Perry et al., 1987). The sequence of degenerative events comprises cellular and molecular changes, and requires effective Schwann cell (SC) and macrophage responses (Stoll et al., 1989). Indeed, following injury, SCs dedifferentiate, proliferate, and align in "bands of Büngner" providing structural guidance and growthpromoting substrates to regenerating axons (Vargas and Barres, 2007). SCs also participate in the clearance of myelin debris, which occurs during the first few days postinjury (Stoll et al., 1989) and release a wide variety of chemokines and cytokines, which in turn recruit circulating macrophages to the degenerating nerve (Shamash et al., 2002; Siebert et al., 2000; Tofaris et al., 2002). Macrophages mediate the second phase of myelin debris removal, a type-3 complement receptor-dependent mechanism (CR-3/Mac-1/CD11b) (Slobodov et al., 2001). All these events are orchestrated by a network of cytokines and chemokines, of which the induction is partly regulated by the activation of the transcription nuclear factor kappa B (NF-кB) signaling pathway $(\mathrm{Fu}$ et al., 2010; Subang and Richardson, 2001), as well as by neurotrophic factors, secreted both by SCs and macrophages: interleukin-1beta (IL1- $\beta$ ) (Perrin et al., 2005; Shamash et al., 2002), IL-6 (Bolin et al., 1995), tumornecrosis factor alpha (TNF- $\alpha$ ) (Shamash et al., 2002), monocyte chemotactic protein-1 (MCP-1) (Perrin et al., 2005), macrophage inflammatory protein-1 alpha (MIP$1 \alpha$ ) (Perrin et al., 2005), nerve growth factor (NGF) (Funakoshi et al., 1993) and vascular endothelial growth factor (VEGF) (Scarlato et al., 2003). Placental growth factor (PlGF), belonging to the VEGF family, has not been implicated in WD up to now. Identified in 1991 in the placenta (Maglione et al., 1991), PlGF has also been detected in heart, lung, thyroid, skeletal muscle (Persico et al., 1999) and brain (Beck et al., 2002). There are 3 isoforms of PlGF in humans, but only one, PlGF-2, is present in mice (DiPalma et al., 1996). Mice

Grant sponsor: K.U.Leuven (Federal Government-Belgium); Grant number: IUAP06/30; Grant sponsor: Methusalem funding (Flemish Government, Concerted Research Activities); Grant number: GOA2006/11; Grant sponsors: National Fund for Scientific Research (Belgium), Charcot Foundation (Belgium), "Gunter Verbraeckel" Foundation (private foundation, Belgium), ABMM association from Belgium, "Leon Fredericq" foundation (University of Liege).

*Correspondence to: Franzen Rachelle, GIGA Neurosciences, Axonal Regeneration and Cephalic Pain Unit, University of Liege, Tour de Pathologie B36, +1, Avenue de l'Hôpital, 1, 4000 Liege, Belgium. E-mail: rfranzen@ulg.ac.be

Received 23 June 2010; Accepted 18 October 2010

DOI 10.1002/glia.21108

Published online 6 December 2010 in Wiley Online Library (wileyonlinelibrary. com). 
in which the PlGF gene has been deleted $\left(P g f^{-/-}\right.$mice) do not exhibit any defects in development or reproduction, but show impaired angiogenesis in pathological conditions (Autiero et al., 2003a,b; Carmeliet et al.,2001; Ribatti, 2008). PlGF is produced by activated endothelial cells (ECs), inflammatory cells, bone marrow cells, as well as neurons (Beck et al., 2002; Luttun et al., 2002). Interestingly, PlGF displays pro-inflammatory properties: it mobilizes macrophages, has a chemotactic activity on blood monocytes (Clauss et al., 1996) and increases mRNA expression of pro-inflammatory cytokines and chemokines such as TNF- $\alpha$, IL-1 $\beta$, IL-8, MCP-1, MIP-1 $\alpha$, and VEGF (Bottomley et al., 2000; Perelman et al., 2003; Selvaraj et al., 2003). Recently, PlGF was found to have neuroprotective and angiogenic effects in cerebral ischemia (Liu et al., 2006), but its precise role in the nervous system remains elusive.

Considering the above-described properties of $\mathrm{PlGF}$, we decided to study its expression in peripheral nerves under physiological and degenerative conditions, to investigate the signaling pathway that regulates its expression and to explore its role in the inflammatory context of WD, using a model of sciatic nerve transection in adult wild-type (wt) and $P g f^{-/-}$mice.

\section{MATERIALS AND METHODS Animals}

Adult (10-12 weeks), 50\%Swiss-50\%129SV female wt and $P g f^{-/-}$mice were used (Vesalius Research Center, Pr Carmeliet, KUL, Belgium). The experiments were performed in accordance with the rules and regulations of the Ethical Committee for animal research of the Belgian National Fund for Scientific Research.

\section{Surgical Procedure: Sciatic Nerve Complete Transection}

Mice were anesthetized by intraperitoneal (i.p.) injection of a mixture of ketamine $\left(75 \mathrm{mg} / \mathrm{kg}\right.$; Ketalar ${ }^{\circledR}$, Bayer HealthCare, Brussel, Belgium) and xylazine $(10 \mathrm{mg} / \mathrm{kg}$; Rompun $^{\circledR}$, Pfizer, Brussel, Belgium). Under aseptic conditions, sciatic nerves were exposed and WD induced by a complete axotomy of the nerves at the upthigh level. Proximal and distal stumps were left in their original position to allow axonal regeneration. Muscles and skin were carefully closed in two layers.

\section{Tissue Processing}

Mice were killed after different survival times (1, 3, 7, 14,21 , and 28 days postinjury) by an overdose of Nembutal (150 mg/kg, i.p., CEVA Santé Animale, Brussel, Belgium) and the distal parts of the transected sciatic nerves were freshly harvested, embedded in Tissue-Tek ${ }^{\circledR}$ O.C.T. ${ }^{\mathrm{TM}}$ Compound (Labonord SAS, Templemars, France) and directly frozen. Ten micrometer-thick longi- tudinal or transverse sections were collected onto gelatin-coated slides, and stored at $-20^{\circ} \mathrm{C}$ until used.

Dorsal root ganglions (DRG) from the lumbar segment were harvested from uninjured mice, directly frozen, before being cryosectioned for further immunofluorescent staining.

\section{Primary Schwann Cell Culture}

Adult SCs were isolated from sciatic and trigeminal nerves of wt and $P g f^{-1-}$ mice as described (Bouquet et al., 2007). After careful dissection under sterile conditions, nerves were left for 2 weeks in degeneration medium: DMEM, $10 \%$ foetal bovine serum, Fungizone $(2.5$ $\mathrm{mg} / \mathrm{mL}, \mathrm{GIBCO}^{\circledR}$, Invitrogen ${ }^{\mathrm{TM}}$, Carlsbad, CA), Forskolin (2 mM, Calbiochem ${ }^{\circledR}$, Darmstadt, Germany), Gentamycine $(50 \mathrm{mg} / \mathrm{mL}, \mathrm{GIBCO})$ and Heregulin- $\beta 1$ (10 ng/ mL, HRG; R\&D Systems GmbH, Wiesbaden, Germany) at $37^{\circ} \mathrm{C}, 5 \% \mathrm{CO}_{2}$. After enzymatic and mechanical dissociation, cells were plated on precoated poly-L-lysine (50 $\mu \mathrm{g} / \mathrm{mL}$, Sigma-Aldrich, Saint Louis, MO) and laminin $(10 \mu \mathrm{g} / \mathrm{mL}$, Sigma-Aldrich) T25 culture dishes and incubated at $37^{\circ} \mathrm{C}, 5 \% \mathrm{CO}_{2}$ in $\mathrm{N} 2{ }^{\mathrm{HRG}}$ medium: $50 \% \mathrm{DMEM}$ $50 \% \mathrm{~F} 12$ supplemented with $\mathrm{N} 2\left(\mathrm{GIBCO}^{\circledR}\right)$, gentamycin $(50 \mu \mathrm{g} / \mathrm{mL})$, fungizone $(2.5 \mu \mathrm{g} / \mathrm{mL})$, forskolin $(2 \mu \mathrm{M})$, and HRG (10 ng/mL). At confluence, SCs were purified by magnetic cell-sorting using the anti-low affinity NGF receptor (p75NGFr; AB1554; 1/200; Millipore, Temecula, $\mathrm{CA})$ antibody (Ab), according to the manufacturer's instructions (Miltenyi Biotech $\mathrm{GmbH}$, Bergisch Gladbach, Germany).

\section{Immunofluorescent Stainings}

To characterize PlGF expression, double immunofluorescenct stainings for PIGF (sc-27134; 1:50; Santa Cruz Biotechnology, Santa Cruz, CA, Taylor and Goldenberg, 2007) and NF-H (MAB5448/clone TA51; 1:500; Millipore, De Girolamo et al., 2000) for axons, Neu-N (MAB377/ clone A60; 1:250; Millipore, Borsani et al., 2010) for neuronal cell nuclei, S100 (ZO311; 1/200; DakoCytomation, Gould et al., 1986) for quiescent SCs, p75NGFr (AB1554; 1/200; Millipore, Runyan and Phelps, 2009) for proliferating SCs, von Willebrand factor (vWF; AB6994; 1/2000; Abcam, Yin et al., 2010) for endothelial cells, patched-1 (Ptc-1; sc-9016/H-267; 1/50; Santa Cruz Biotechnology, Chen et al., 2007) for fibroblasts, CD11b (MCA74; 1/250; Serotec, Springer et al., 1979) for macrophages, P0 (AB9352; 1/50; Millipore) for peripheral myelin, were performed. After drying, tissue sections were fixed in cold acetone for $10 \mathrm{~min}$ at $4^{\circ} \mathrm{C}$. Nonspecific binding was prevented by $1 \mathrm{~h}$ incubation in $10 \%$ normal serum solution in $0.1 \%$ triton-PBS (0.1 M, pH 7.4). Sections were then incubated overnight at room temperature (RT) with the specific primary Abs, rinsed 3 times with PBS and incubated with their respective secondary Abs coupled with rhodamine or FITC (1/500, Jackson ImmunoResearch Laboratories, West Grove, Pennsylva- 

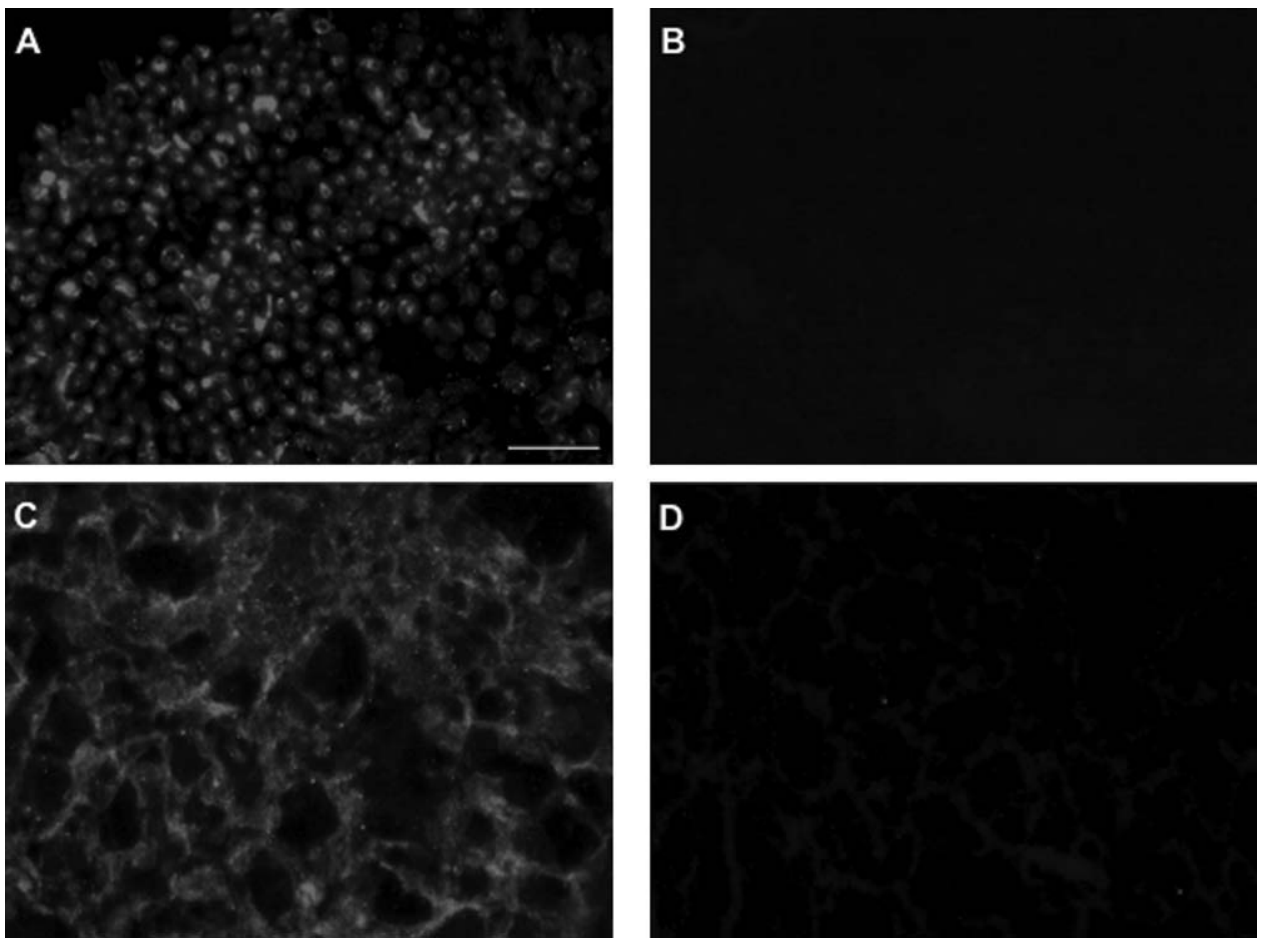

Fig. 1. Confirmation of PlGF Ab specificity. (A) PlGF immunostaining on transverse section of sciatic nerve. (B) Negative control: nerve section stained with anti-PlGF Ab preincubated with its specific blocking peptide. (C) PlGF immunostaining on placenta used as positive control tissue and (D) on liver used as negative control tissue. Scale bar: $60 \mu \mathrm{m}$.

nia), for $1 \mathrm{~h}$ at RT. Sections were then rinsed twice in PBS, twice in distilled water, and mounted under coverslips using vectashield solution (Vector Laboratories, Burlingame, CA). To assess the specificity of the antiPlGF Ab, negative controls were obtained by incubation of the primary $\mathrm{Ab}$ with its specific blocking peptide (sc27134 P; Santa Cruz Biotechnology) before applying it on the tissue sections. Also, specific positive (placenta) and negative (liver) tissues for PlGF were used to confirm this specificity (Fig. 1).

\section{Prediction of NF- $\kappa$ B Binding Sites and Luc Assay}

To identify NF- $\mathrm{B}$ binding sites, computational analysis of the promoter sequence of mouse Pgf gene (Green et al., 2001) was performed using four different programs designed to look for transcription factor binding sites (MatInspector program, Match ${ }^{\text {TM }}$ program, Promo, TFSEARCH).

For luciferase assays, the region including the two $\kappa \mathrm{B}$ sites were inserted into the pGL3-Promoter Vector (Promega). 293 cells $\left(4 \times 10^{5}\right.$ cells per well) were seeded in 6-well $(35 \mathrm{~mm})$ plates. After $12 \mathrm{~h}$, cells were transfected as described above with $0.5 \mu \mathrm{g}$ of either the Pgf$\kappa \mathrm{B}$-luciferase or the Ig- $\kappa \mathrm{B}$-luciferase (Leonardi et al., 2000) and with expression plasmids as indicated. The total amount of transfected DNA was kept constant by adding empty expression vector DNA as needed. Cell extracts were prepared $24 \mathrm{~h}$ after transfection, and reporter gene activity was determined by using Dual-Luciferase Reporter Assay System (Promega). The pRL Vector $(40 \mathrm{ng})$, which provides constitutive expression of Renilla luciferase, was used to normalize for transfection efficiencies.

\section{Chromatin Immunoprecipitation (ChIP) Assay}

Sciatic nerves (from uninjured [UI] and 24h postinjured wt mice) were surgically removed from four adult mice per condition, minced and immediately fixed in PBS containing 1\% paraformaldehyde (PFA) for $25 \mathrm{~min}$ at RT. The nerves were washed twice with cold PBS containing protease inhibitors (Complete ${ }^{\mathrm{TM}}$, Roche Applied Science, Mannheim, Germany) and then homogenized into $1.5 \mathrm{~mL}$ of lysis buffer (1\% SDS, $10 \mathrm{mM}$ EDTA, 50 $\mathrm{mM}$ Tris-HCl $\mathrm{pH}$ 8.0, protease inhibitors). The lysates were sonicated for $15 \mathrm{~min}$ with alternating $30-\mathrm{s}$ pulses at high power with a Bioruptor sonicator (Diagenode, Liege, Belgium), and then centrifuged at 13,000 rpm for $5 \mathrm{~min}$. The protein concentration of lysates was measured using the BCA protein assay kit (ThermoScientific, Rockford, Illinois). Inputs were kept for later analysis. Lysates were diluted 10 times into dilution buffer (1\% Triton X-100, $150 \mathrm{mM} \mathrm{NaCl}, 2 \mathrm{mM}$ EDTA, $20 \mathrm{mM}$ Tris- 
TABLE 1. Quantitative PCR probe informations

\begin{tabular}{|c|c|c|c|}
\hline $\begin{array}{l}\text { Amplicon } \\
\text { name }\end{array}$ & $\begin{array}{c}\text { Gene } \\
\text { localization }\end{array}$ & $\begin{array}{l}\text { Primer } \\
\text { type }\end{array}$ & $\begin{array}{c}\text { Oligonucl. } \\
\text { Sequence }\left(5^{\prime}-3^{\prime}\right)\end{array}$ \\
\hline $\begin{array}{c}\text { PlGF kB1 } \\
\text { site }\end{array}$ & -908 to -1015 & $\begin{array}{l}\text { Reverse } \\
\text { Forward }\end{array}$ & $\begin{array}{l}\text { ACGTGCCTCCAGAACCGTCC } \\
\text { CCAGGTGCCCCGAGGTGTTT }\end{array}$ \\
\hline $\begin{array}{l}\text { PlGF kB2 } \\
\text { site }\end{array}$ & -1041 to -1120 & $\begin{array}{l}\text { Reverse } \\
\text { Forward }\end{array}$ & $\begin{array}{l}\text { CTCCTGTCAGGTCAGGCCAGC } \\
\text { CCTCTTCTGCTTGGGCTCGGG }\end{array}$ \\
\hline $\begin{array}{l}\text { PlGF } \\
\text { gene }\end{array}$ & 624 to 753 & $\begin{array}{l}\text { Reverse } \\
\text { Forward }\end{array}$ & $\begin{array}{l}\text { TTCCCCTTGGTTTTCCTCCTT } \\
\text { AGATCTTGAAGATTCCCCCCA }\end{array}$ \\
\hline
\end{tabular}

$\mathrm{HCl} \mathrm{pH}$ 8.0, protease inhibitors). The sheared chromatin was incubated with $4 \mu \mathrm{g}$ of anti-NF-кB subunit p65 (p65; sc-109, Santa Cruz Biotechnology) or anti-Flag (used as negative control; F3165, Sigma-Aldrich) at $4^{\circ} \mathrm{C}$ on a rotating platform overnight. The immune complexes were incubated for 2 hours at $4^{\circ} \mathrm{C}$ with Protein A-agarose beads (Santa Cruz Biotechnology) blocked with BSA $(100 \mu \mathrm{g} / \mathrm{mL})$ and shared salmon sperm DNA (500 $\mu \mathrm{g} / \mathrm{mL}$; Invitrogen $\left.{ }^{\mathrm{TM}}\right)$. The immunoprecipitates were then washed three times with $1 \mathrm{~mL}$ low salt washing buffer ( $1 \%$ triton X-100, 0.1\% SDS, $150 \mathrm{mM} \mathrm{NaCl}, 2 \mathrm{mM}$ EDTA, $20 \mathrm{mM}$ Tris-HCl $\mathrm{pH}$ 8.0, protease inhibitors), once with $1 \mathrm{~mL}$ high salt washing buffer (same buffer but containing $500 \mathrm{mM} \mathrm{NaCl}$ ), once with $1 \mathrm{~mL} \mathrm{LiCl}$ buffer (0.25 M LiCl, 1\% IGEPAL CA630 (Sigma-Aldrich), $1 \mathrm{mM}$ EDTA, $1 \%$ deoxycholic acid, $10 \mathrm{mM}$ Tris- $\mathrm{HCl} \mathrm{pH}$ 8.0 ), and finally once $1 \mathrm{~mL}$ with TE buffer (10 mM Tris$\mathrm{HCl} \mathrm{pH}$ 8.0, $1 \mathrm{mM}$ EDTA). Immunoprecipitated (IP) chromatin was eluted in $250 \mu \mathrm{L}$ elution buffer (1\% SDS, $0.1 \mathrm{M} \mathrm{NaHCO}_{3}$ ) for $15 \mathrm{~min}$ at RT, twice. Chromatin inputs were also diluted in elution buffer. Protein-DNA cross-links were reversed by incubation with $20 \mu \mathrm{L}$ of 5 $\mathrm{M} \mathrm{NaCl}$ at $65^{\circ} \mathrm{C}$ for $4 \mathrm{~h}$ and proteins were digested by addition of $10 \mu \mathrm{L}$ of $0.5 \mathrm{M}$ EDTA, $20 \mu \mathrm{L}$ of $1 \mathrm{M}$ Tris- $\mathrm{HCl}$ $\mathrm{pH} 6.5$ and $20 \mu \mathrm{g}$ of proteinase $\mathrm{K}$ (Promega, Madison, Wisconsin) and incubation $1 \mathrm{~h}$ at $45^{\circ} \mathrm{C}$. DNA was purified with phenol/chloroform (Sigma-Aldrich) using Phase Lock Gel ${ }^{\mathrm{TM}}$ tube (Eppendorf, Hamburg, Germany). The aqueous phase was incubated $1 \mathrm{~h}$ at $-20^{\circ} \mathrm{C}$ after the addi-

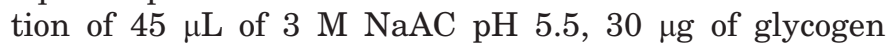
(Roche Applied Science) and $1 \mathrm{~mL}$ of absolute ethanol and then centrifuged $5 \mathrm{~min}$ at $13,000 \mathrm{rpm}$. The DNA pellets were washed with $70 \%$ ethanol, resuspended in $100 \mu \mathrm{L}$ of DNase-free distilled water. Quantitative PCR (using SYBR green PCR master mix; Applied Biosystems) was performed to analyse the IP DNA. Signals were normalized to respective inputs and compared with negative control (anti-Flag IP). The primers (Eurogentec, Seraing, Belgium) used to amplify specific $\kappa \mathrm{B}$ sites of Pgf gene are resumed in Table 1.

\section{Axonal Regeneration Study}

To evaluate axonal regeneration, longitudinal sections from the distal part of injured sciatic nerves were fluorescently stained with anti-NF-H Ab as described above. For the quantification, nonoverlapping successive fields covering the entire tissue sections (which means the whole length of the distal part) were taken using Olympus DP50 digital camera connected to an Olympus AX70 microscope (magnification 10x). The mean number of fields/section was similar between wt and $\mathrm{Pg} f^{-1-}$ mice $(7.47 \pm 0.76$ and $7.54 \pm 0.64$, respectively), resulting in comparable total tissue length. Each field was then allocated to one of the following group: (i) field containing only debris of degenerating axons; (ii) field containing a majority of debris and few regenerating profiles; (iii) field containing scarce debris and a majority of regenerating fibers; and (iv) field containing only regenerating fibers. Data were expressed as a mean proportion of field numbers in each of those 4 groups per total nerve section $(\%) \pm$ standard error.

\section{Motor Recovery Evaluation}

Before lesion and at 3, 7, 10, 14, 17 and 21 days following unilateral left sciatic nerve axotomy, mice were allowed to walk down a $60 \mathrm{~cm}$ long corridor lined with graph paper after inking their hind paws. For each animal (5 wt and $5 P g f^{-/-}$mice), at every time point, at least four clear footprints were obtained for each foot. Measurements of print length were then made on the operated side (OPL) and the normal side (NPL). A mean of four values was then calculated for the OPL (xOPL) and NPL (xNPL), and a print-length factor (PLF) was calculated as follows: $\mathrm{PLF}=(\mathrm{xOPL}-\mathrm{xNPL}) / \mathrm{xNPL}$ (George et al., 2003).

\section{Quantification of Schwann Cell Proliferation}

\section{In vivo}

Longitudinal sections of sciatic nerves were stained with anti-Ki67 $\mathrm{Ab}$ according to the above-described protocol (NCL-Ki67p; 1/250; Novocastra ${ }^{\mathrm{TM}}$, Leica Microsystems $\mathrm{GmbH}$ ). Ki67 positive SC nuclei (magnification $20 x$ ) were manually counted within nonoverlapping successive fields covering the entire nerve section, and results were expressed as a mean number \pm standard error of Ki67 positive SC nuclei per $\mathrm{mm}^{2}$ of nerve tissue.

\section{In vitro}

Cultured SCs were plated on coated glass coverslips at a concentration of 25,000 cells $/ 300 \mu \mathrm{L}$. $20 \mu \mathrm{M}$ bromodeoxyuridine (BrdU; Sigma-Aldrich) was directly added to the cultures for $16 \mathrm{~h}$ before fixation in $4 \%$ PFA for $10 \mathrm{~min}$. Cells were treated in $\mathrm{HCl} 2 \mathrm{~N}$ for $10 \mathrm{~min}$ at $37^{\circ} \mathrm{C}$ and then washed in borate buffer (0.1M; pH 8.5). Cells were permeabilised and nonspecific binding was prevented by $1 \mathrm{~h}$ incubation in $10 \%$ normal serum $0.1 \%$ triton-PBS solution. Then cells were incubated overnight with anti-BrdU Ab (OBT0030; 1/250; Serotec) and antip75NGFr Ab to assess the purity of SC culture. After 3 PBS washes, cells were incubated with their respective 
TABLE 2. RT-PCR probe informations

\begin{tabular}{cccc}
\hline Gene & Primer type & \multicolumn{1}{c}{ Oligonucleotide sequence $\left(5^{\prime}-3^{\prime}\right)$} & PCR product size $($ bp $)$ \\
mPlGF & Reverse & TTCCCCTTGGTTTTCCTCCTT & 130 \\
& Forward & AGATCTTGAAGATTCCCCCCA & 45 \\
GAPDH & Reverse & GCCTTCTCCATGGTGGTGAAGAC & 210 \\
& Forward & GACCCCTTCATTGACCTCAACTACATG & 25 \\
\hline
\end{tabular}
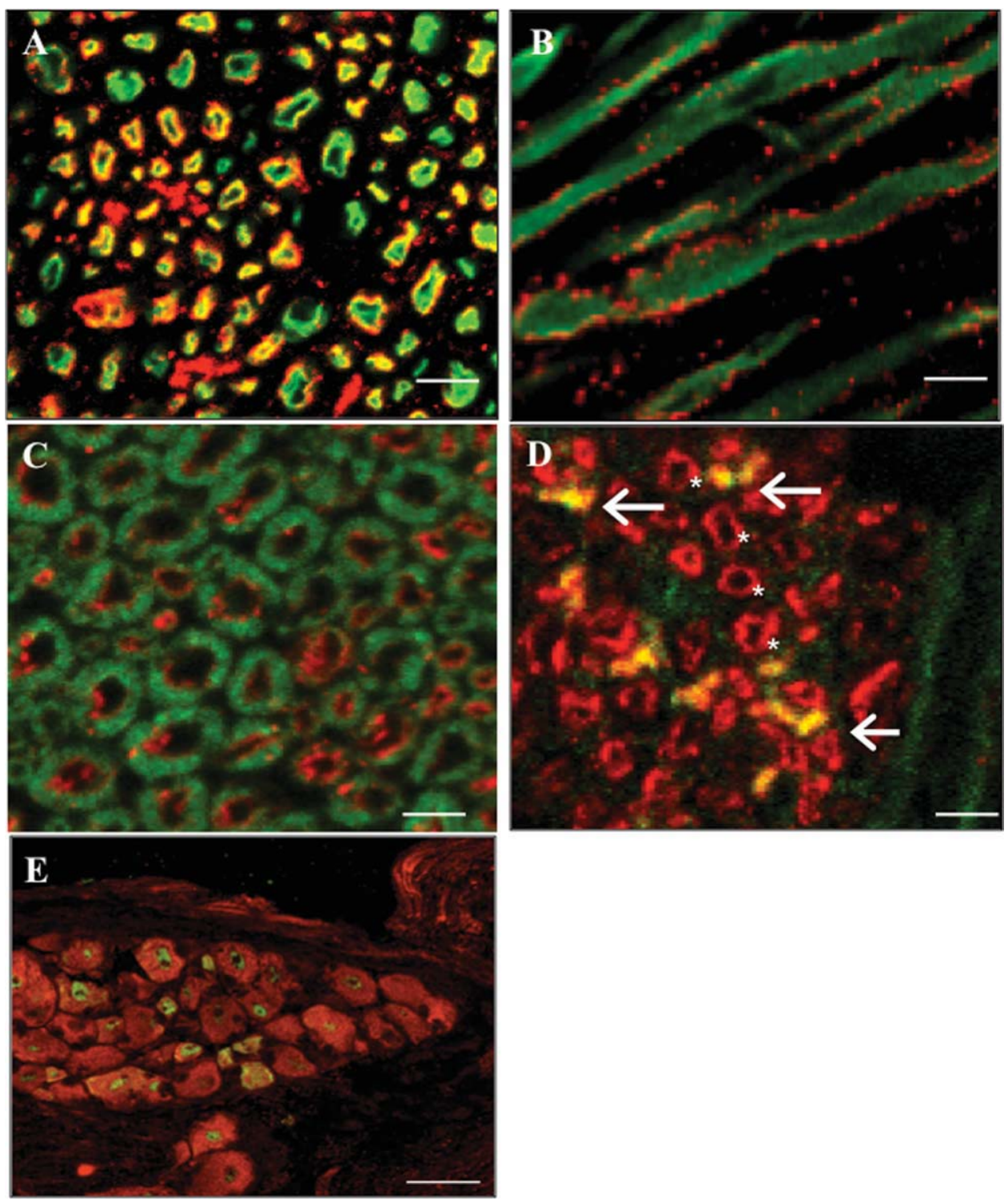

Fig. 2. Double immunofluorescent stainings on uninjured sciatic nerve (A-D) and dorsal root ganglion (E) sections. PlGF (Rhodamine) and NF (A, B), P0 (C), Ptc-1 (D), NeuN (E) (FITC) double immunofluorescent stainings, on transverse $(\mathrm{A}, \mathrm{C}, \mathrm{D})$ and longitudinal $(\mathrm{B})$ sections of uninjured sciatic nerve. PlGF is expressed in axons and has a peri-

axonal expression pattern (A, B). However, PlGF is not present in the myelin sheath, as no co-localization could be seen with P0 (C). Finally, besides its periaxonal localization, PlGF is also expressed by fibroblasts in the endoneurium ( $\mathrm{D}$, arrows show PIGF/Ptc-1 labelled fibroblasts, and * design axons). Scale bar: A, C, D: $20 \mu \mathrm{m}$; B: $10 \mu \mathrm{m}, \mathrm{E}: 50 \mu \mathrm{m}$.

secondary Abs coupled with rhodamine or FITC, for $1 \mathrm{~h}$ at RT. Coverslips were then rinsed in PBS and distilled water, and mounted on slides using vectashield solution containing DAPI to visualize all nuclei for the determination of the total cell number. Double-stained
p75NGFr/BrdU cells and total number of p75NGFr positive cells (magnification 20x) were manually counted within nonoverlapping successive fields, and results were expressed as a mean $\% \pm$ standard error of proliferating SCs. 

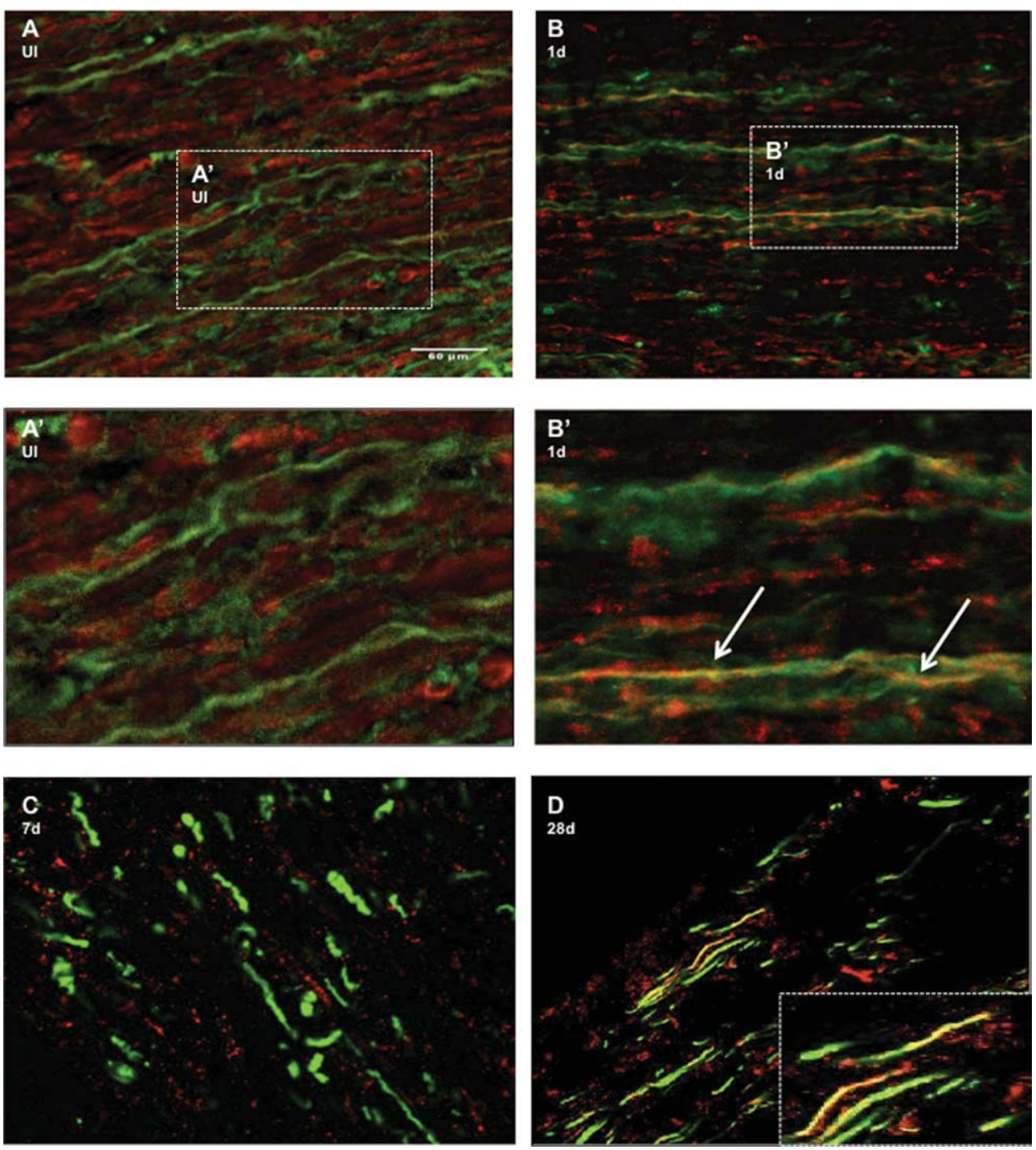

Fig. 3. Double immunofluorescent stainings on normal and injured sciatic nerve sections. PlGF (Rhodamine) and S100 (A, $\left.\mathbf{A}^{\prime}\right)$, p75NGFr $\left(\mathbf{B}, \mathbf{B}^{\prime}\right)$ or NF (C, D) (FITC) double immunostainings, on longitudinal sections of normal $\left(\mathrm{A}, \mathrm{A}^{\prime}\right.$ ) and injured (distal segment, $\mathrm{B}, \mathrm{B}^{\prime}, \mathrm{C}$, and $\mathrm{D}$ ) sciatic nerves. PIGF is not expressed by myelinating SCs, as no co-local-

\section{RT-PCR}

RNA from cultured SCs was extracted with TRIzol ${ }^{\circledR}$ (Invitrogen ${ }^{\mathrm{TM}}$ ) and isolated according to the manufacturer's protocol. PIGF and glyceraldehyde 3-phosphate dehydrogenase (GAPDH, as internal control), mRNAs were amplified with aliquot of $20 \mathrm{ng}$ of total RNA using a RT-PCR kit (GeneAmp Thermostable rTth reverse transcriptase RNA PCR kit; Applied Biosystems, Foster City, CA) and appropriate "forward" and "reverse" primers (oligonucleotide sequences shown in Table 2; Eurogentec, Seraing, Belgium). Reverse transcription was performed at $70^{\circ} \mathrm{C}$ for 15 minutes followed by 2 minutes of incubation at $95^{\circ} \mathrm{C}$ for denaturation of RNA-DNA heteroduplexes. Amplification consisted in cycles of 15 seconds at $94^{\circ} \mathrm{C}, 20$ seconds at $58^{\circ} \mathrm{C}$, and 20 seconds at $72^{\circ} \mathrm{C}$. RT- ization is observed with $\mathrm{S} 100\left(\mathrm{~A}, \mathrm{~A}^{\prime}\right)$. SCs, which dedifferentiate and proliferate after loss of axonal contact, express PlGF from the first day after injury $\left(\mathrm{B}, \mathrm{B}^{\prime}\right)$. Axonal PlGF expression decreases after injury, following the time course of axonal degradation (C). 28 days postinjury, PIGF reappears in the regenerating fibres (D). Scale bar: $60 \mu \mathrm{m}$.

PCR products were resolved on $10 \%$ polyacrylamide gel, stained with GelStar (Lonza, Rockland, Maine).

\section{DAB Immunostainings}

Tissues were fixed with $4 \%$ PFA for $5 \mathrm{~min}$, then incubated in a $0.3 \% \mathrm{H}_{2} \mathrm{O}_{2}, 0.1 \% \mathrm{Na}$ azide solution in PBS for $20 \mathrm{~min}$ at RT to reduce endogenous peroxydase activity. Nonspecific binding was prevented by $1 \mathrm{~h}$ incubation in $3 \%$ normal serum and $1 \%$ bovine serum albumin solutions in $0.1 \%$ triton-PBS. Sections were then incubated overnight at RT with the specific Abs: anti-p75NGFr (AB1554; 1/200; Millipore) to study SC dedifferentiation or anti-CD11b (MCA74; 1/250; Serotec) to study macrophage recruitment. After 3 PBS rinses, they were incu- 
bated with their respective secondary biotinylated antibodies (Vector Laboratories) diluted and centrifuged in a $3 \%$ mouse normal serum and $1 \%$ BSA in $0.1 \%$ tritonPBS solution, for $1 \mathrm{~h}$ at RT. Then sections were incubated $1 \mathrm{~h}$ with the avidin-biotin-peroxydase complex (Vector Laboratories), diluted 1/1000 in PBS and the immunostaining revealed with 3,3 '-diaminobenzidine.

\section{Image Analysis}

To quantify SC dedifferentiation, pictures (magnification 20x) were converted to gray scale. A threshold intensity of gray-colored staining was set and applied to each slice. Then, immunostaining was quantified within nonoverlapping successive fields covering the total nerve tissue area using the Olympus AnalySIS computer program. Data were expressed as the mean integral intensity \pm standard error of total stained area $\left(\right.$ pixel $\left.^{2}\right)$ per total nerve tissue area $\left(\mathrm{pixel}^{2}\right.$ ). For the macrophage recruitment quantification, CD11b-positive macrophages (magnification 10x) were manually counted within nonoverlapping successive fields covering the entire nerve section, and results were expressed as a mean number \pm standard error of CD11b-positive macrophages per 0.1 $\mathrm{mm}^{2}$ of nerve tissue.

\section{Toluidine Blue Staining}

Mice were perfused with Karnovski solution containing $1 \% \mathrm{PFA}$ and $1.25 \%$ glutaraldehyde in $0.2 \mathrm{M}$ Sorensen buffer $(\sim 750 \mathrm{mOsm})$. Sciatic nerves were carefully harvested and postfixed with Karnovski overnight at $4^{\circ} \mathrm{C}$. After two washes in $0.1 \mathrm{M}$ Sorensen buffer, nerves were postfixed with $1 \%$ osmium in Sorensen buffer for $1 \mathrm{~h}$ at $4^{\circ} \mathrm{C}$. Sciatic nerves were progressively dehydrated in successive ethanol baths and then soaked in epoxypropane twice during $10 \mathrm{~min}$ each. Tissues were embedded in epon resin by soaking in a mixture of epoxypropane/ epon in proportions $2 / 1$, then $1 / 1$ and finally $1 / 2$, $1 \mathrm{~h}$ each. The resin was harded at $265^{\circ} \mathrm{C}$ for 2 days. The blocks were trimmed and semi-thin transverse sections $(1 \mu \mathrm{m})$ were cut with a Leica Ultracut UCT microtome, picked up onto glass slides, and then dried on a hot plate at $60^{\circ} \mathrm{C}$ for $1 \mathrm{~h}$. To have a good dye impregnation in the tissue, sections were treated with $1 \%$ potassium tetraborate before staining with $0.5 \%$ toluidine blue. Intact myelin sheaths (magnification 40x) were manually counted within nonoverlapping successive fields covering the entire nerve section, and results were expressed as a mean number \pm standard error of intact myelin sheaths per $0.01 \mathrm{~mm}^{2}$ of nerve tissue.

\section{Cytokine Array}

Expressions of IL- $1 \alpha$, IL-1 $\beta$, IL-6, TNF- $\alpha$, IL-10, VEGF, VEGF receptor-1 (VEGFr1), MCP-1, MIP-1 $\alpha$ and the pro-matrix metalloprotease-9 (proMMP-9) were

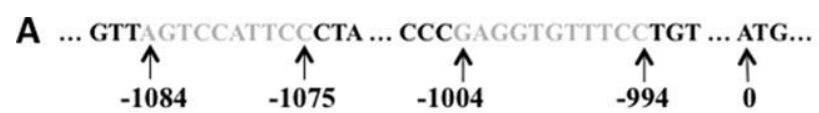

B
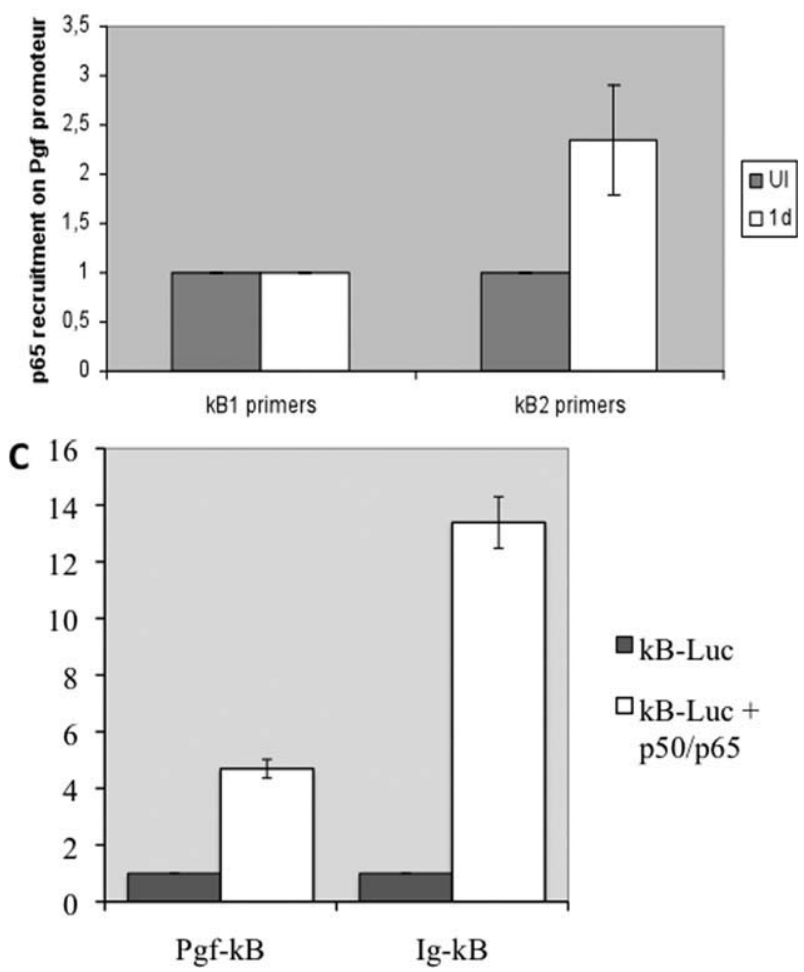

Fig. 4. NF-kB binding on Pgf gene promoter after sciatic nerve injury. (A) The prediction of NF- $\mathrm{NB}$ binding sites has revealed two putative $\kappa \mathrm{B}$ motifs (grey letters) located at positions 994-1004 ( $\kappa \mathrm{B} 1)$ and 1075-1084 ( $\mathrm{BB} 2)$ bps upstream the ATG translation initiation site of the mouse Pgf gene. (B) p65 is specifically recruited to the $P g f$ gene promoter after injury, as examined by chromatin immunoprecipitation assays using normal uninjured sciatic nerves (UI) or 1 day-injured sciatic nerves (1d). After normalization to inputs and to negative flag IP, signal in UI condition was set to 1 and the one obtained in injured condition was expressed relative to it. Results are from three independent experiments and error bars denote standard deviation. We observed no fold induction for the $\mathrm{kB} 1$ primers. (C) The $\kappa \mathrm{B}$ sites found in the Pgf promoter are functional in activating $\mathrm{NF}-\kappa \mathrm{B}$, as examined by Luciferase assay. Pgf-kB or Ig-kB (positive control) vectors were transfected in 293 cells, with or without the p50/p65 expression vectors, as indicated. Signals were normalized by measuring Renilla activity of a co-transfected pRL vector. For each vector, the value obtained in the absence of p50/p65 was set to 1 and the other was expressed relative to it. Results are from three independent experiments and error bars denote standard deviation.

measured in tissue extracts of UI and injured sciatic nerves from wt and $\mathrm{Pg} f^{-1-}$ mice using RayBio ${ }^{\circledR}$ Cytokine Antibody Arrays (RayBiotech, Norcross, Georgia). $200 \mu \mathrm{g}$ of total protein were used per sample. The cytokine array membranes were scanned with a Las-4000 luminescent image analyser (Fujifilm, Tokyo, Japan). The intensity of the signal was measured with the Quantity One 1-D Analysis software (Bio-RAD Laboratories, Hercules, CA). The results were expressed as the mean relative signal intensity, i.e. the ratio of sample signal intensity/positive control signal intensity. Each signal intensity of positive controls and samples was normalized by the background substraction. 

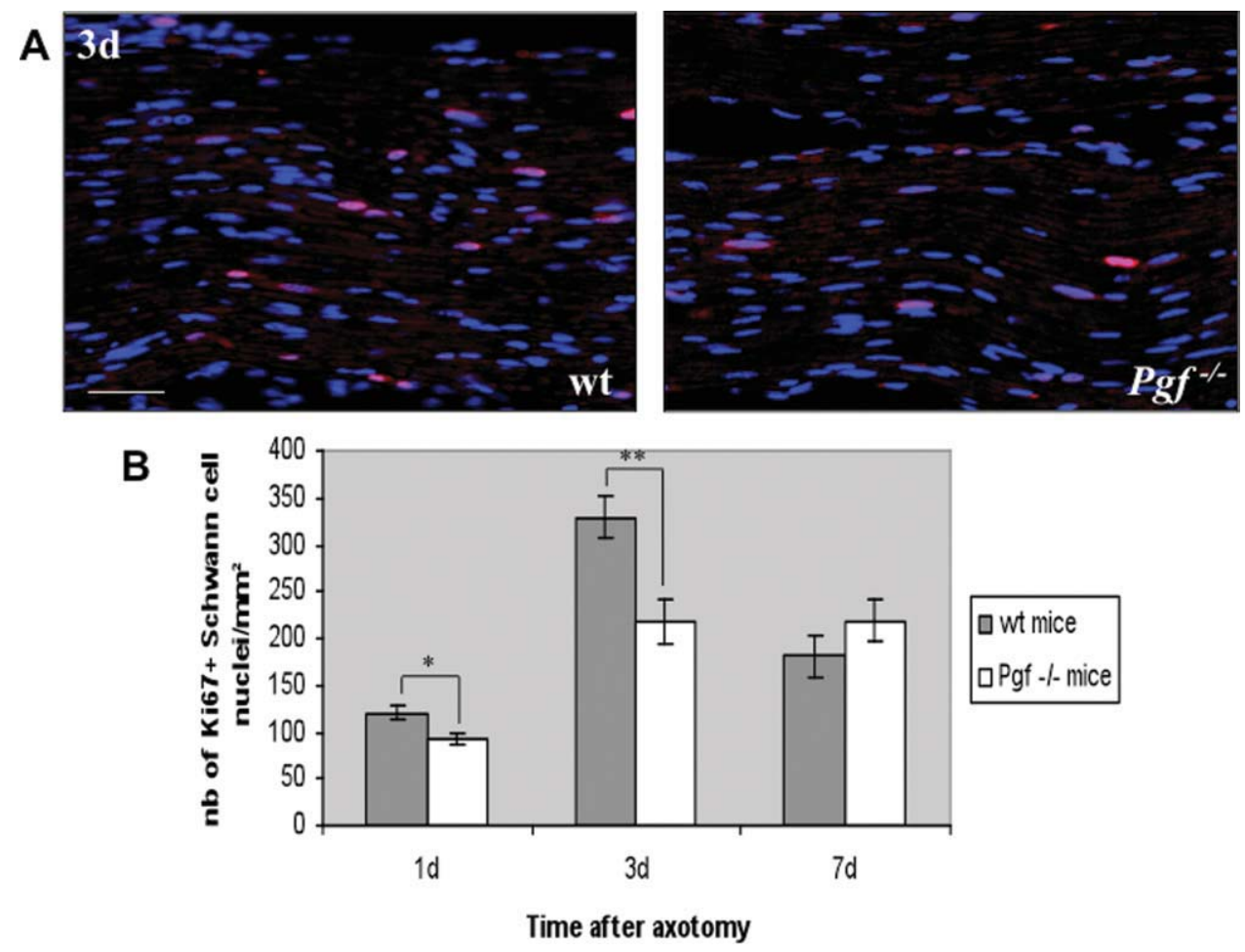

\begin{abstract}
Fig. 5. In vivo cell proliferation. (A) Ki67 immunoreactivity in longitudinal sections of wt and Pgf ${ }^{-}{ }^{-}$sciatic nerves 3 days after axotomy (scale bar: $\left.50 \mu \mathrm{m}\right)$. (B) Cell quantification shows a significant difference between wt and $P g f^{-/-}$mice in the number of Ki67 positive cells 1 and 3 days postinjury. $* * P<0.01 ; * P<0.05$ (mean $\pm \mathrm{SE} ; N=5$ mice per group).
\end{abstract}

\section{Statistical Analysis}

Means and standard errors for each experimental time point were calculated. Statistical significance was set at $P<0.05$. The statistical significances between wt and $P g f^{-/-}$mice were tested separately at each time points using a Student t-test (for CD11b, NGFr immunostaining and Toluidine blue quantifications).

To evaluate the group effect in motor recovery during time (foot-print data), we used Zerbe's nonparametric model, which compares both the global evolution of two groups and the values at the different time point separately. All quantifications were performed blind to the genotype. Statistical analyses were supervised by the Department of Biomedical Statistics of the University of Liege.

\section{RESULTS \\ PIGF Expression in Normal and Injured Adult Mouse Sciatic Nerve}

To investigate PIGF expression in the normal nerve and after axotomy, we performed various double immunofluorescent stainings to screen all cell types and/or structures present in the nerve: axons, myelin, myelinating and proliferating SCs, fibroblasts, ECs, and invading macrophages.
Based on PlGF/NF double staining, PlGF is found within the axons of the normal sciatic nerve and more precisely at the periphery of axons (Fig. 2A,B). This expression is found in close contact with, but not within the myelin sheath, as no co-localization can be seen with the P0/PlGF double staining (Fig. 2C). Fibroblasts within the endoneurium, labeled with the Ptc- $1 \mathrm{Ab}$, express PlGF (Fig. 2D). to further assess neuronal expression of PlGF, we also performed PlGF/NeuN double immunofluorescent staining on lumbar dorsal root ganglion sections, where neuronal cell bodies are located. This staining clearly shows that PlGF is expressed within the neuronal cell body (Fig. 2E). Finally, vWF Ab, used to identify endothelial cells, never co-localized with PlGF (data not shown). PlGF/S100 staining confirms that myelinating Schwann cells (SCs) do not express PlGF (Fig. 3A, $\mathrm{A}^{\prime}$ ). After nerve transection, the detection of proliferating SCs by immunostaining with p75NGFr interestingly shows that PlGF is seen in these cells as soon as 1 day postaxotomy (Fig. 3B, $\mathrm{B}^{\prime}$ ) and persists during the first week after injury (data not shown). Concomitantly, PlGF is no more detectable in the degenerating fibres (Fig. 3C). When axonal regeneration occurs, starting as soon as 14 days postinjury, PlGF-positive fibres reappear in the distal segment of the sciatic nerve (Fig. 3D). Finally, after injury, no PlGF was observed in invading macrophages nor in ECs (data not shown). 

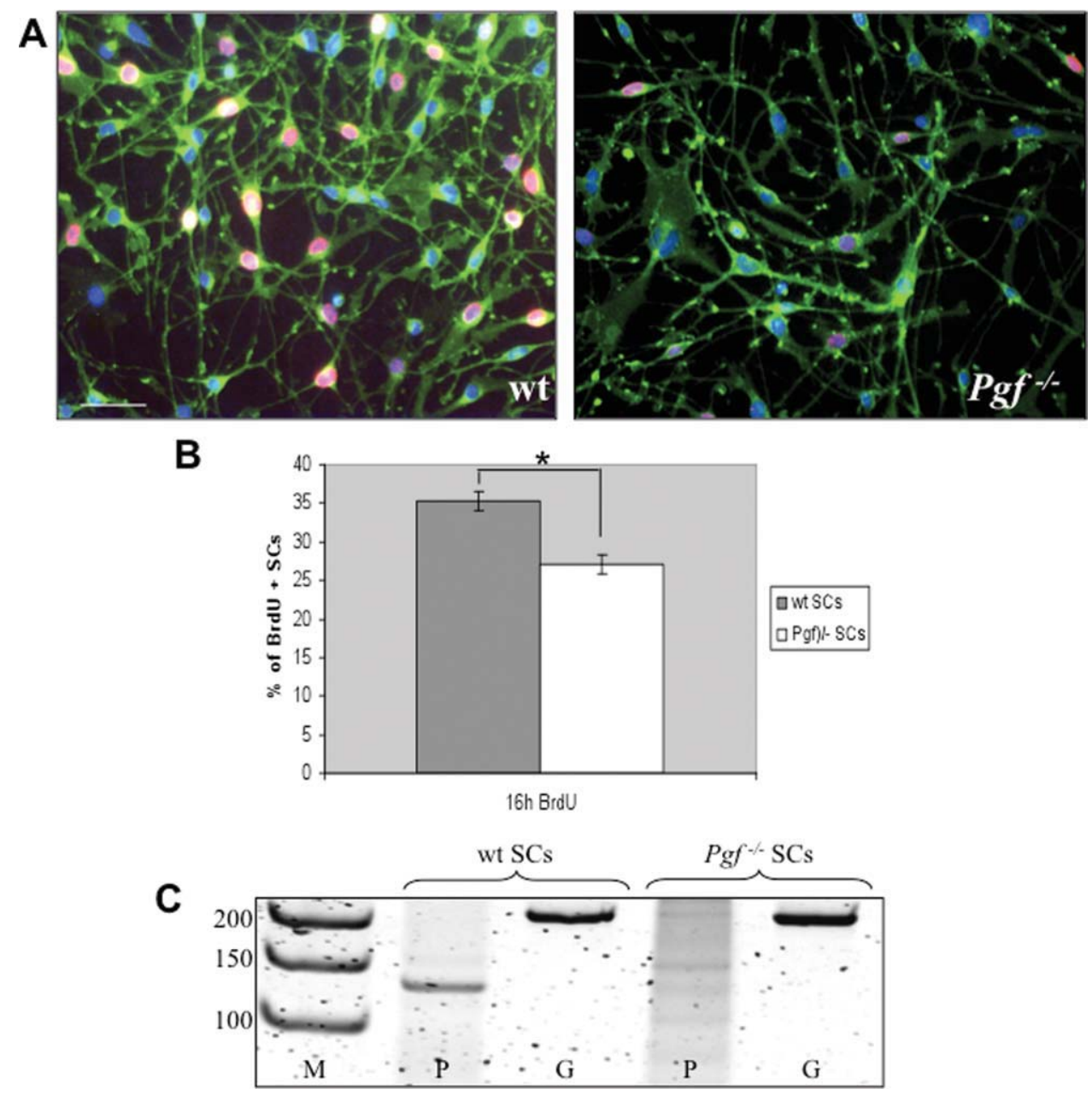

Fig. 6. In vitro Schwann cell proliferation. (A) BrdU (rhodamine)/ p75NGFr (FITC) immunostaining of wt and $\mathrm{Pgf}{ }^{-1-}$ SCs after BrdU incorporation (scale bar: $50 \mu \mathrm{m}$ ). (B) Quantification shows a significant decrease of $P g f^{-1-}$ SC proliferation. $* P<0.05$ (mean $\pm \mathrm{SE} ; N=3$ cul-

\section{PIGF Expression Induction: Role of NF-kB}

During WD, one of the main transcription factor that regulates the cyto- and chemo-kine expression by SCs is NF-кB (Fu et al., 2010; Subang and Richardson, 2001). As we demonstrated that PlGF is expressed by SCs in a postinjury inflammatory context, we investigated the potential implication of $\mathrm{NF}-\kappa \mathrm{B}$ in the induction of PlGF expression during WD by ChIP assay. Firstly, we analysed the $\operatorname{Pgf}$ promoter sequence, using transcription factor binding site prediction programs, to identify putative $\kappa \mathrm{B}$ motifs on the mouse Pgf promoter. We detected the presence of two putative NF- $\mathrm{BB}$ binding sites within the mouse Pgf promoter region (Fig. 4A). To investigate the NF- $\kappa \mathrm{B}$ binding to these two $\kappa \mathrm{B}$ motifs, we immunoprecipitated the chromatin, from UI and one day-injured sciatic nerves, using an anti-p65 Ab. DNA fragments of IP chromatin were amplified by quantitative PCR, using primers specifically designed to amplify predicted $\kappa \mathrm{B} 1$ or кB2 site (Table 1). The Fig. 4B shows a threefold ture experiments). (C) Polyacrylamide gel showing PlGF (P) and GAPDH (G) RT-PCR amplification products from wt and Pgf ${ }^{-/}$cultured SCs. RT-PCR confirmed PlGF expression in wt SCs in culture conditions and, as expected, no expression in $\mathrm{Pgf}^{-1-} \mathrm{SCs}$.

increase in $\mathrm{NF}-\kappa \mathrm{B}$ binding to the $\kappa \mathrm{B} 2$ site after injury compared with UI nerve controls, whereas no significant recruitment of $\mathrm{NF}-\kappa \mathrm{B}$ was observed to the $\kappa \mathrm{B} 1$ site. To further prove that the sites were functional in activating gene expression, they were inserted into a luciferase re-

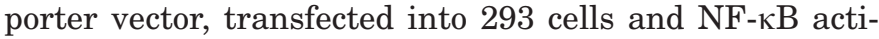
vation was assessed upon co-transfection with two NF$\kappa \mathrm{B}$ subunits, p50 and p65. As shown in the Fig. $4 \mathrm{C}$, the $\kappa \mathrm{B}$ sites found in the $P g f$ promoter $(\operatorname{Pgf}-\kappa \mathrm{B})$ were indeed functional as the p50/p65 heterodimer induced luciferase gene expression (about 4-5 fold).

\section{PIGF in WD}

\section{Role of PIGF on Schwann cell proliferation and formation of Büngners' bands}

The WD process in the distal stump of the injured nerve is associated with activation and proliferation of $\mathrm{SCs}$, which form the bands of Büngner and express 

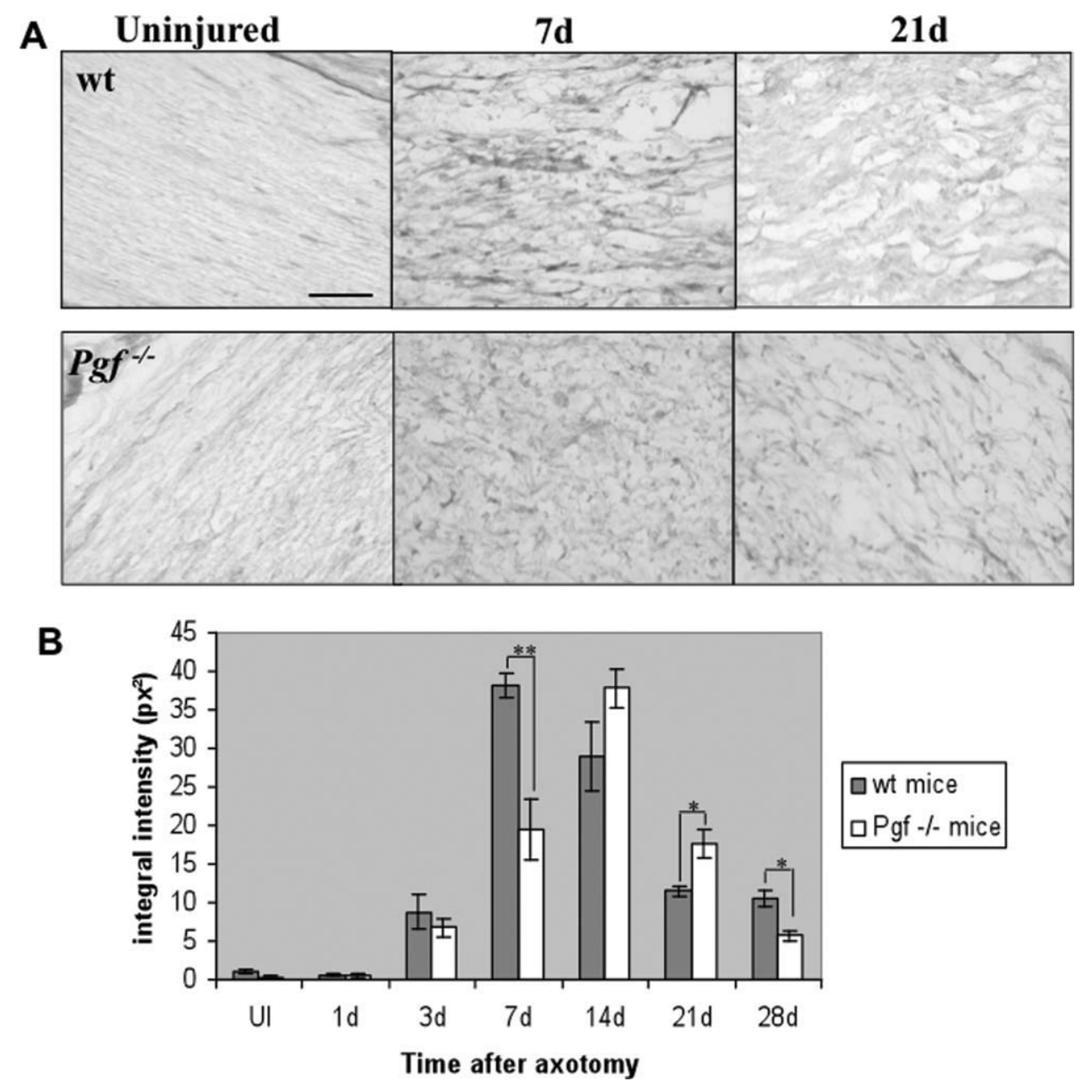

Fig. 7. P75NGFr immunostaining and quantification. (A) P75NGFr immunoreactivity in longitudinal sections of wt and $P g f^{-1-}$ sciatic nerves before (UI) and after axotomy (scale bar: $\left.100 \mu \mathrm{m}\right)$. (B) Image analysis and staining quantification show a significant difference between wt and $P g f^{-/-}$mice in the intensity of P75NGFr staining 7, 21 and 28 days postinjury. $* * P<0.01 ; * P<0.05$ (mean \pm $\mathrm{SE} ; N=5-9$ mice per group).

p75NGFr. To assess the role of PlGF in these processes, we compared the proliferation of SCs within the sciatic nerves of wt and $P g f^{-1-}$ mice after axotomy. Using immunofluorescent staining against Ki67, a nuclear protein expressed in cells undergoing proliferation, we quantified the number of proliferating cells at 1, 3 and 7 days after axotomy in the distal stump of nerves from wt and $P g f^{-1-}$ mice (Fig. 5A,B). We found a significant decrease of cell proliferation in $P g f^{-1-}$ mice at 1 and 3 days postinjury (Fig. 5B). Because of a conflict between Abs, we were not able to perform the double immunofluorescent staining Ki67/p75NGFr to identify the proliferating cells as SCs. We can nevertheless attest that the Ki67-positive cells are not inflammatory cells, such as invading macrophages, as they do not express CD11b (data not shown).

To confirm the in vivo finding of decreased SC proliferation in mice lacking PlGF, we compared the proliferation of primary cultures of SCs isolated from wt or $P g f^{-1-}$ mice. Using BrdU incorporation and double im- munofluorescent staining against BrdU and p75NGFr (Fig. 6A), we counted the mean number of proliferating SCs. The number of BrdU positive $P g f^{-/-}$SC nuclei was significantly decreased (Fig. 6B). To attest that SCs express PIGF in culture condition, which corresponds to the proliferating state they adopt after a nerve injury, we performed a RT-PCR for PIGF on RNA extracts from wt and $P g f^{-1-}$ SC cultures, using $G A P D H$ as housekeeping gene. The polyacrylamide gel showing RT-PCR amplification products (Fig. 6C) confirmed a PlGF expression in proliferating wt SCs. We then assessed p75NGFr expression in wt and $P g f^{-1-}$ mice after several post-transection survival times. As illustrated in Fig. 7, p75NGFr is weakly expressed in UI nerves (Fig. $7 \mathrm{~A})$. In wt animals, its expression increases 3 days after axotomy and reaches a peak at day 7 (Fig. 7B). At that time, the longitudinal aspect of the p75NGFr staining is likely due to the alignment of SCs to form the bands of Büngner, still observed 14 days after the lesion. In Pgf ${ }^{-1-}$ mice, the peak of expression of p75NGFr is only 

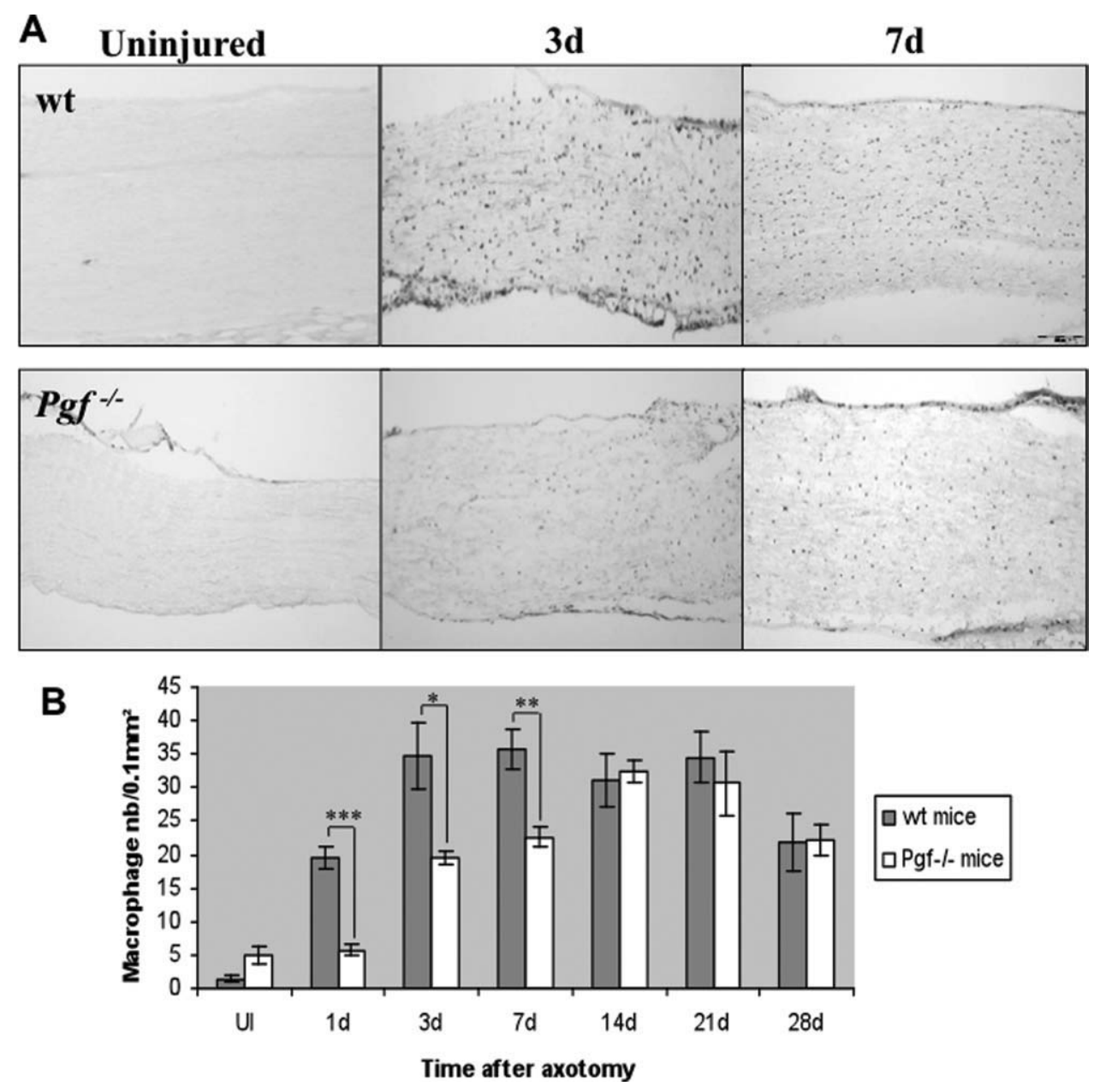

Fig. 8. CD11b immunostaining and quantification. (A) CD11b immunostaining of longitudinal sections of wt and $P g f^{-1-}$ sciatic nerves before (UI) and after axotomy (scale bar: $200 \mu \mathrm{m}$ ). (B) Cell quantification shows a significant difference between wt and $\mathrm{Pgf}{ }^{-1-}$ mice in the number of invading macrophages 1,3 , and 7 days postinjury. ${ }^{*} * P<0.001$; $* * P<0.01 ; * P<0.05$ (mean \pm SE; $N=5-12$ mice per group).

reached 14 days after the lesion, and decreases more rapidly afterwards. Also, at day 7 , the longitudinal aspect of the staining is much less pronounced than in tissue sections of wt animals (Fig. 7A).

\section{Role of PIGF on macrophage recruitment and myelin sheath degradation}

The other main cell type involved in the WD process are macrophages, which accumulate within the degenerating nerve segment and facilitate the removal of axonal and myelin debris. As PlGF plays a role in the chemo-attraction of macrophages (Clauss et al., 1996), we first quantified the number of invading macrophages within the degenerating segment at several postinjury times, comparing wt and $\mathrm{Pgf}{ }^{-/-}$mice. CD11b immunostaining of longitudinal nerve sections revealed a clear delay in the macrophage infiltration in $P g f^{-1-}$ nerves respective to wt nerves (Fig. 8A). While infiltration peaked between the 3rd and the 7th day postinjury in wt mice, it did so only between 14 and 21 days in $P g f^{-1-}$ tissue (Fig. 8B). To verify if this delay affects the degradation of myelin sheaths, we stained the latter with toluidine blue and counted them on semi-thin transverse wt and $P g f^{-1-}$ nerve sections at various survival times (Fig. 9A). These counts clearly confirmed that the clearance of myelin sheaths is slower in $P g f^{-1-}$ mice (Fig. 9B).

\section{Role of PIGF on cytokine and chemokine expression}

WD is orchestrated by a large cyto-/chemo- kine network, which regulates SC and macrophage functions. As PlGF absence affects more particularly early events of $\mathrm{WD}$, we compared the expression of 10 cyto/chemokines in extracts of UI, and 1, 3 and 7 days- injured sciatic nerves from wt and $\mathrm{Pgf}{ }^{-I^{-}}$mice. The following molecules were studied: IL- $1 \alpha$, IL-1 $\beta$, IL-6, IL-10, TNF- $\alpha$, VEGF, VEGFr1, MCP-1, MIP-1 $\alpha$ and proMMP-9. The 


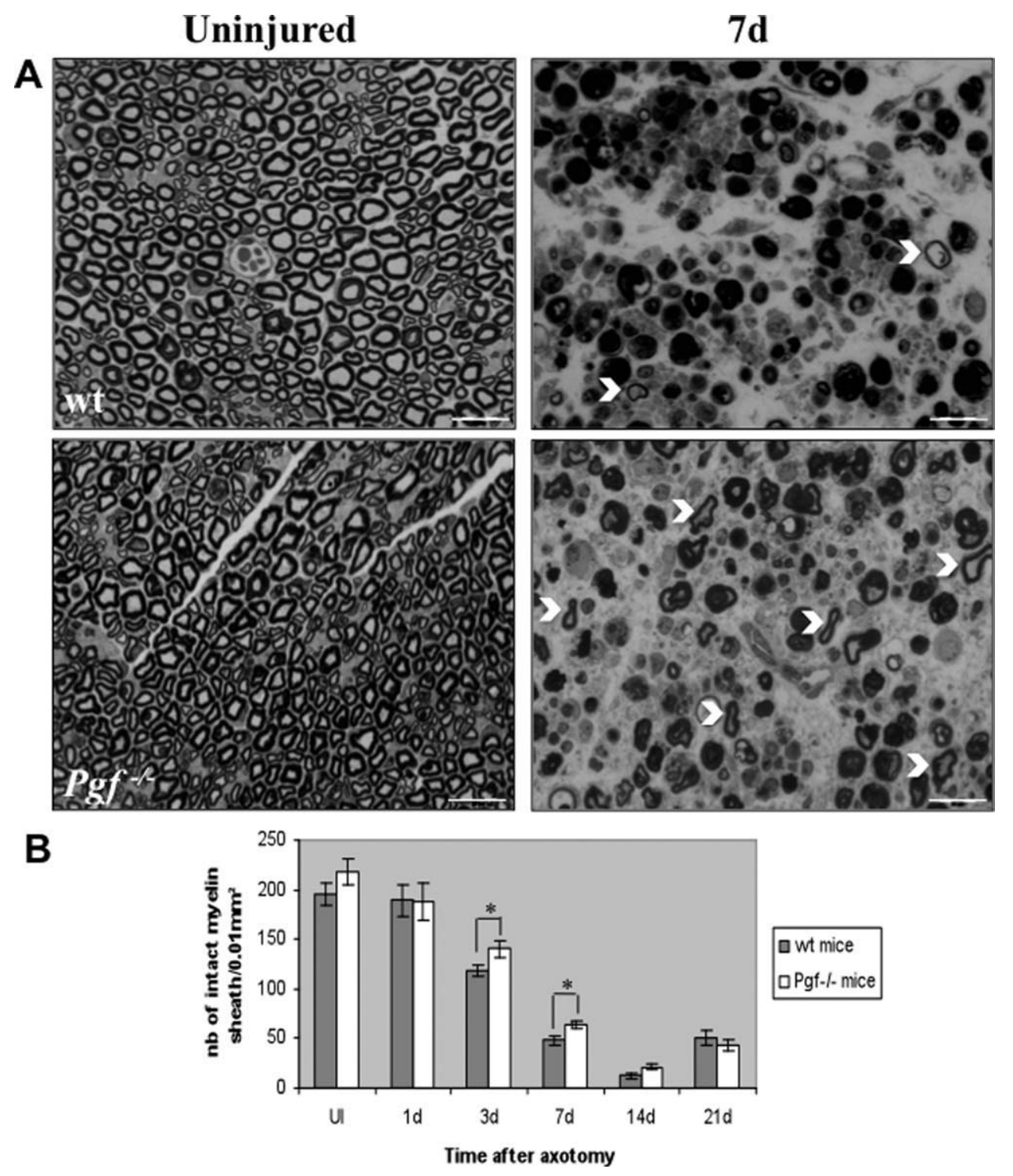

Fig. 9. Myelin sheath quantification. (A) Toluidine blue staining on semithin transverse sections from wt and $P g f^{-1-}$ sciatic nerves before (UI) and 7 days after axotomy (scale bar: $20 \mu \mathrm{m}$ ). Quantification shows a significant difference between wt and $P g f^{-1-}$ mice in the number of intact myelin sheaths (white arrowheads) 3 and 7 days postinjury. ${ }^{*} P<0.05$ (mean $\pm \mathrm{SE} ; N=5-9$ mice per group).

quantitative analysis of the signal intensity revealed significant decreases in $P g f^{-1-}$ extracts of MCP-1 at 1 day, and proMMP-9 at 7 days postinjury $(P<0,05)$ (Fig. 10).

\section{Role of PIGF in axonal regeneration and functional recovery}

As SC and macrophage functions appear to be delayed during WD in $P g f^{-1-}$ animals, axonal regeneration might also be altered. To test this hypothesis, we compared the NF-H immunostainings of transected sciatic nerves in wt and $P g f^{-1-}$ mice. At 7 days postinjury, all axons are degraded in both wt and $P g f^{-1-}$ nerve distal parts, as illustrated by the high number of axonal debris (Fig. 11A). At 14 days, regeneration starts in wt nerves, as more longitudinal profiles can be observed in wt than in $P g f^{-1-}$ nerves. This observation was confirmed by counting the proportion of fields containing either axonal debris (dotted aspect of NF staining), axonal profiles (longitudinal profiles on NF staining), or both (Fig. 11B). Almost $60 \%$ of the total length of the nerve corresponds to fields containing only axonal debris in $\mathrm{Pg} f^{-/-}$mice, while debris-containing fields occupy less than $10 \%$ in wt mice. As a corollary, fields with higher proportions of regenerating axons occupy $50 \%$ of the nerve length in wt mice compared with less than $5 \%$ in $P g f^{-/-}$mice. No field containing only axonal profiles was observed 14 

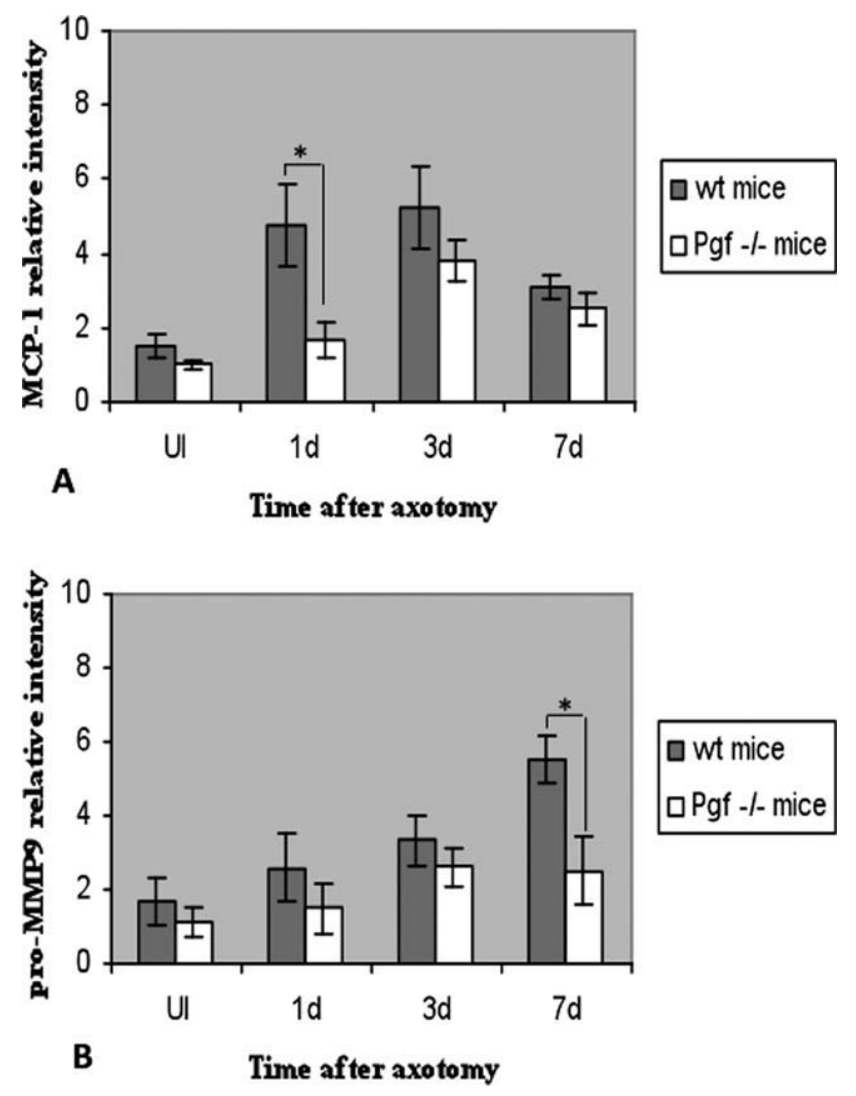

Fig. 10. Cytokine arrays on sciatic nerve extracts from wt and Pgf mice. (A) MCP-1 doesn't increase its expression in $P g f^{-1-}$ nerve as much as in wt nerves 1 day after injury. (B) Pro-MMP-9 peaks at 7 days postinjury only in wt nerves. ${ }^{*} P<0.05$ (mean $\pm \mathrm{SE} ; N=6$ mice per group).

days postinjury. After 21 days, regenerating profiles were more numerous, reflecting the repair progress, and there were no more difference between wt and Pgf ${ }^{-1-}$ mice. This finding suggests therefore that absence of PlGF leads to a transient delay of axonal regeneration. To assess the consequence of this delayed axonal regeneration on functional recovery, we further evaluated motor recovery after sciatic nerve axotomy in $P g f^{-1-}$ compared with wt mice, using the walking track method in which footprints are analysed (Fig. 12A). The print-length of uninjured (NPL) and injured (OPL) sciatic nerves were measured preoperatively, as well as $3,7,10,14,17$ and 21 days after axotomy and were used to calculate the print-length factor (PLF, described in Methods section). During the first week following injury, this PLF increases and reaches after 7 days the value of about 0.5 and 0.35 for wt and $P g f^{-1-}$ mice, respectively, indicating a marked disability in the injured paw. At day 10, the PLF of wt mice starts to decrease and reaches a value of about 0.3 at 21 days after injury, whereas the PLF of Pgf ${ }^{-1-}$ mice continues to get worse and reaches a value of about 0.6 at 21 days. Figure 12B illustrates the recovery of motor function determined by the PLF. We observe no functional recovery for the $P g f^{-1-}$ mice. ${ }^{* *} P<0.01$; ${ }^{*} P<$ 0.05 (mean $\pm \mathrm{SE} ; N=5$ mice per group).

\section{DISCUSSION}

This study provides evidence of a new function for PIGF within the PNS, where its expression had never been described. Using immunohistochemistry, double immunofluorescent stainings, in vivo and in vitro cell proliferation assays, cytokine arrays, RT-PCR, foot-prints, Luc assay and ChIP assay, we propose an original model for PlGF role in the inflammatory context of WD (Fig. 13).

\section{PIGF is Expressed in the Peripheral Nervous System}

Since its initial discovery in the placenta in 1991, PlGF has been found in other organs, including the brain (Beck et al., 2002). Until now, nothing was known about its distribution in the PNS. As the goal of our study was to investigate its potential role in WD in a model of sciatic nerve injury, the first part of our work focused on the expression of PlGF in the sciatic nerve. Using immunostaining on intact nerve and DRG, we are providing evidence that PlGF is expressed in neuronal cell bodies and axons, but not in SCs, nor in myelin sheaths. The peculiar peri-axonal localization of PlGF could be due to its particular basic carboxyl end that confers him the ability to bind polyanionic molecules like acidic phopholipids of cell membranes (Autiero et al., 2003a; De Falco et al., 2002; Persico et al., 1999).

\section{PlGF Expression During WD}

Axotomy results in axonal breakdown and disintegration, which can explain the decrease of PlGF expression observed in injured axons during the first week postinjury. Thereafter, WD in the PNS leads to successful axonal regeneration, explaining the re-expression of PlGF in axons. Our results also show that SCs transiently express PlGF after nerve injury. An induction of VEGF expression in injured peripheral nerves has been previously reported (Höke et al., 2001; Scarlato et al., 2003). Axonal rupture causes a loss of contact between the axolemma and its corresponding SC that switches from a differentiated state to an undifferentiated, proliferating state. This SC response is, among others, due to a neuronal release of the cytokine TGF- $\beta 1$, which induces SC proliferation (Rogister et al., 1993). Interestingly, TGF$\beta 1$ has been shown to activate PlGF expression in cultured keratinocytes (Failla et al., 2000) and in retinal pigment epithelial cells (Hollborn et al., 2006). Hence, the transient expression of PlGF in SC observed after injury might be due to axonal released TGF- $\beta 1$.

\section{PIGF: A Target of NF-кB}

The NF- $\mathrm{BB}$ factor plays important roles in immune, inflammatory and apoptotic responses through the induction of the transcription of numerous genes coding 

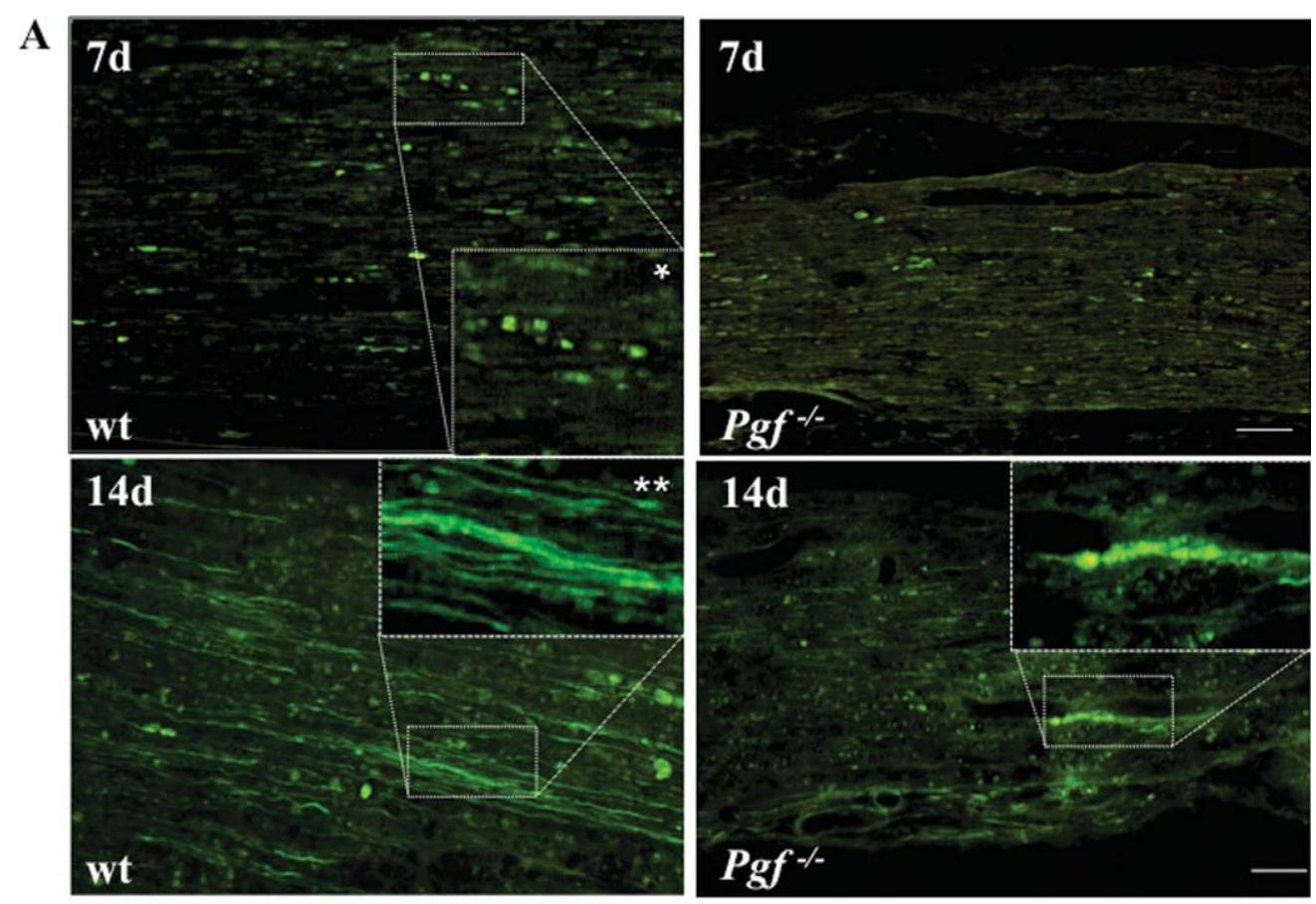

B

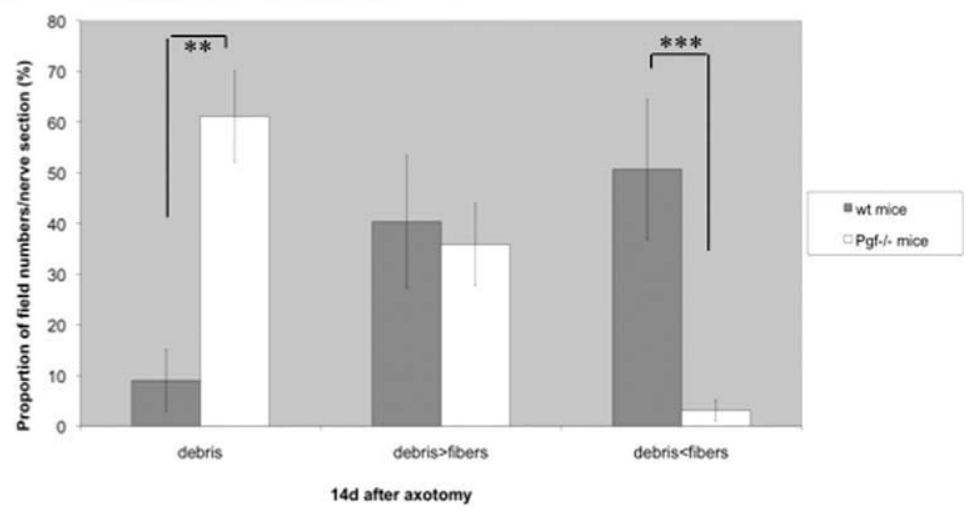

Fig. 11. Neurofilament immunostaining and semiquantification. (A) $\mathrm{NF}$ immunostaining on longitudinal sections of wt and $P g f^{-1-}$ sciatic nerves 7 and 14 days after axotomy (scale bar: $100 \mu \mathrm{m}$ ). Inserts illustrate representative fields considered as "debris (*)" or "fibres (**)." (B)
Quantification shows that after 14 days, $P g f^{-1-}$ nerves contain a significant higher proportion of debris than wt nerves, while more regenerating profiles are observed in wt nerves than $P g f^{-1-}$ ones. ${ }^{* * * P}<$ $0.001 ; * * P<0.01$ (mean $\pm \mathrm{SE} ; N=5-7$ mice per group). for pro-inflammatory cytokines (Ledeboer et al., 2005; Vallabhapurapu and Karin, 2009), chemokines (Giraud et al., 2010; Grove and Plumb, 1993), matrix metalloproteases (Hnia et al., 2008; Rhee et al., 2007), and adhesion molecules (Haddad et al., 2010; Moynagh et al., 1994). After axotomy, activation of NF- $\mathrm{NB}$ in SCs is also implicated in the regulation of the inflammatory response occurring during WD (Fu et al., 2010; Subang and Richardson, 2001). Previous study has revealed that human PlGF expression during hypoxia was regulated by NF- $\mathrm{BB}$ (Cramer et al, 2005). Our results of chromatin immunoprecipitation assay agree with the fact that $\mathrm{PlGF}$ transcription is regulated by the NF- $\mathrm{B}$ signalling pathway. By Luciferase assay, we further confirmed that the $\kappa \mathrm{B}$ sites found in the $P g f$ promoter are functional in activating $\mathrm{NF}-\kappa \mathrm{B}$.

\section{PIGF Deletion Causes a Delay in Cellular and Molecular Events of WD}

\section{Lack of PIGF delays Schwann cell dedifferentiation and decreases their proliferation}

Nerve injury stimulates the generation of proliferative nonmyelinating $\mathrm{SCs}$ within $24 \mathrm{~h}$ after the lesion. In $P g f^{-1-}$ mice, SC proliferation rates were shown, both in vitro and in vivo, significantly delayed. Flt-1, which binds both VEGF and PlGF-2, mediates VEGF-triggered proliferation of astroglial cells (Krum et al., 2008; Mani et al., 2005). It is thus possible that in wt animals the PlGF released by injured axons activates Flt-1 receptors on SC membranes hence inducing their proliferation. As 
A
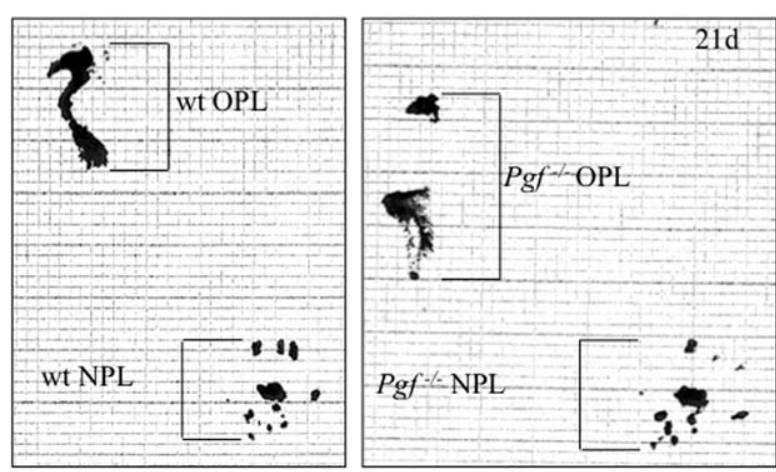

B

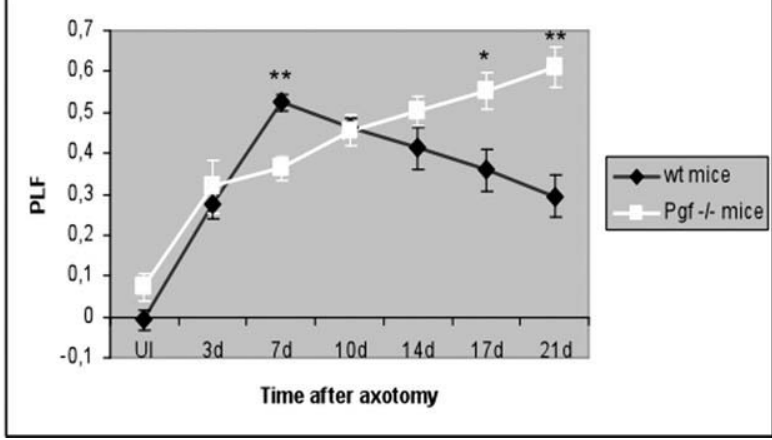

Fig. 12. Functional recovery. (A) Representative footprints obtained from wt and $P g f^{-1-}$ mice, 21 days after unilateral left sciatic nerve transection. Measures of the length of the operated footprints (OPL) and the normal footprints (NPL) were used to calculate the print-length factor (PLF). (B) Graph showing the recovery of motor function after sciatic nerve transection determined by the PLF (described in the Methods section). Worse recovery is evident in mice lacking PlGF compared with their wt controls.

other mitotic agents act on SCs during WD (D'Antonio et al., 2006; Kwon et al., 1997; Li et al., 2005; Ogata et al., 2006), the sole absence of PlGF can only decrease $\mathrm{SC}$ proliferation, but not abolish it.

\section{Lack of PIGF delays macrophage recruitment and myelin clearance}

Macrophages play an essential role during WD. In addition to rapid clearance of axonal and myelin debris, they secrete neurotrophins (Barrette et al., 2008), promoting successful axonal regeneration. PIGF is chemoattractive for macrophages (Clauss et al., 1996), and stimulates chemokine secretion (Selvaraj et al., 2003). It is therefore not surprising to observe a significant delay in macrophage invasion during the first week of WD in $P g f^{-1-}$ mice. This observation is corroborated by our cytokine array results, where significant difference of MCP-1 expression was observed between wt and Pgf ${ }^{-1-}$ mice. Indeed, while MCP-1 rapidly increases after injury in wt nerves, it takes 2 more days before an increase occurs in $P g f^{-1-}$ nerves. MCP-1 mRNA is known to be induced very early after transection in the distal portion of the sciatic nerve (Perrin et al., 2005; Toews et al., 1998). MCP-1 is necessary for specific and full recruit-

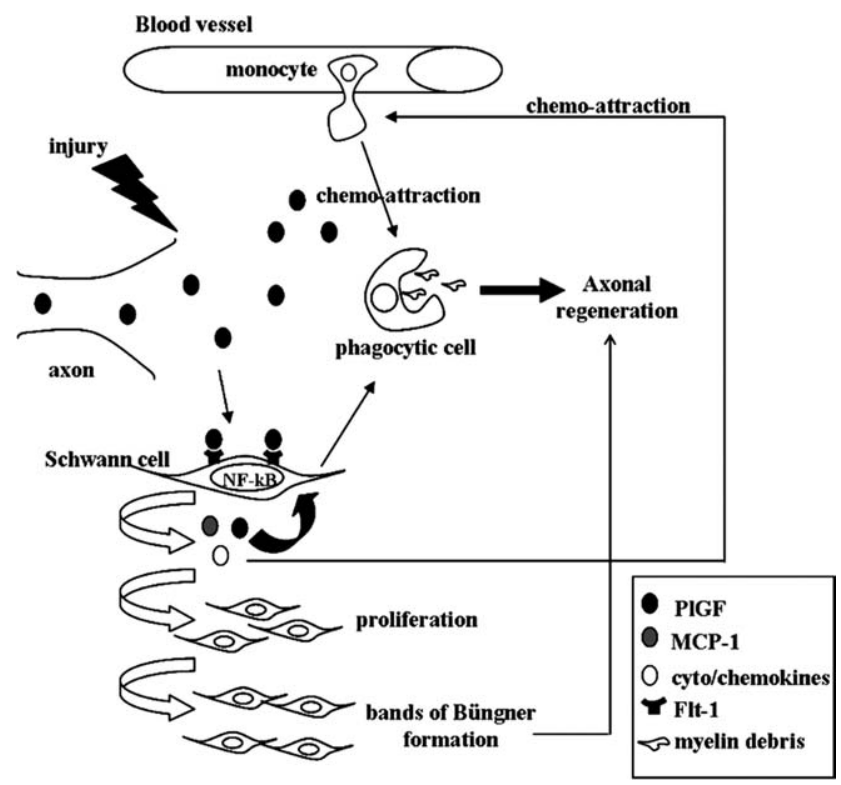

Fig. 13. Model of PlGF function in the injured peripheral nerve. Following axonal breakdown, the released PlGF can bind to its flt-1 receptor on SC, which in turn (i) produces PlGF and chemokines through the activation of the NF- $\mathrm{KB}$ signaling pathway, (ii) proliferate, and (iii) align to form bands of Büngner, promoting axonal regeneration. PlGF also influences directly monocyte chemoattraction, thereby increasing macrophage activity of myelin debris phagocytosis, necessary to successful axonal regeneration.

ment of monocytes during WD (Perrin et al., 2005; Siebert et al., 2000).

The delay observed in myelin degradation and clearance, which is dependent on SCs and macrophages, is therefore the consequence of the delayed recruitment and reduced activity of these two cell types.

\section{Lack of PIGF delays the formation of Büngner's bands}

In addition to their role in the inflammatory response, SCs migrate and line up to form the bands of Büngner. SC migration involves several molecules like cell-signaling factors, integrins, as well as proteases (Lauffenburger and Horwitz, 1996). Among them, MMP-9, which is over-expressed by SCs after nerve injury and promotes SC migration (Mantuano et al., 2008), was found to be a target for PlGF (Hattori et al., 2002). Indeed, our cytokine arrays show a significant decrease of proMMP-9 expression 7 days after injury in $P g f^{-1-}$ mice relative to wt. NGF and its low affinity receptor p75NGFr are also involved in SC migration (Anton et al., 1994) and in our study p75NGFr expression is delayed in $\mathrm{Pgf}^{-1-}$ mice after injury. Interestingly, mice lacking the neuropilin-2 receptor for PIGF-2 do also show a delayed regeneration after sciatic crush injury, due to a delayed reestablishment of contact between axons and SCs (Bannerman et al., 2008). Moreover, it is known that VEGF has migratory effects on SCs mainly through its tyrosine kinase receptors flk-1 and flt-1 (Mani et al., 2010; 
Schratzberger et al., 2000) and that flt-1, the PlGF receptor, mediates migration of endothelial cells (Bae et al., 2005; Li et al., 2006), and retinal pigment epithelial cells (Hollborn et al., 2006). The delay of SC alignment could thus also be related to a dampened action of VEGF, of which the effects are normally amplified by PlGF via various mechanisms (Autiero et al., 2003b; Carmeliet et al., 2001; Ribatti, 2008).

\section{Lack of PIGF delays cyto/chemokine expression}

A large cyto/chemokine network regulates the sequential WD cellular events described above. PlGF is able to induce an increase of several of these molecules like inflammatory cyto/chemokines (Bottomley et al., 2000; Selvaraj et al., 2003) or enzymes such as metalloproteases (Hattori et al., 2002). In our cytokine arrays PlGF has a significant effect on the expression of MCP-1 and proMMP-9. These molecules are essential for early WD events: MCP-1 attracts macrophages (Perrin et al., 2005), and MMP-9 is responsible for SC migration (Mantuano et al., 2008). Thus, PlGF lack of expression can directly affect macrophage invasion as well as MCP-1 and MMP-9 levels of expression. Additionally, as SCs increase their expression of both MCP-1 (Taskinen and Röyttä, 2000) and MMP-9 (Chattopadhyay and Shubayev, 2009) after injury, their delayed proliferation in the absence of PlGF can also trigger a decrease in MCP1 and MMP-9 expression, leading indirectly to a decrease of macrophage activation and a delayed axonal regrowth.

In conclusion, we show that PlGF is involved in the early postaxotomy SC proliferation and macrophage chemoattraction, which can explain that in $P g f^{-1-}$ mice, axonal regeneration and functional recovery are delayed. Indeed, the delay in myelin and axonal debris clearance by SCs and macrophages leads to an unfavorable environment for regeneration. Also, the delay of SC p75NGFr expression and bands of Büngner formation could decrease the beneficial effect that neurotrophins have on the regenerating axons (Taniuchi et al., 1988). This work is the first demonstration of the implication of a new member in the cytokine network regulating $\mathrm{WD}$, the cytokine $\mathrm{PlGF}$, whose function(s) in the intact and injured nervous system were not known up to now. The original observation that PlGF is in particular instrumental in the early events of WD like Schwann cell proliferation and macrophage invasion raises important questions and perspectives for regeneration in the CNS. It is well known indeed that following injury in the CNS, axonal regeneration partly fails because of a less pronounced macrophage invasion compared with PNS. What about PlGF expression after a CNS injury? Could regeneration be promoted by providing PIGF after a CNS lesion? In addition to its potential beneficial effect on the postinjury inflammatory reaction, PlGF treatment could also enhances neo-angiogenesis (Takeda et al., 2009), which is also known to be beneficial to axonal regrowth (Dray et al., 2009; Hobson et al., 2000).

\section{ACKNOWLEDGMENTS}

The authors are grateful to Ms. Mosen, Ms. DiPrima, and Ms. Wouters for their technical assistance to this work. They thank Prof. A. Noel (GIGA-Cancer, Liege, Belgium) for careful reading of the manuscript. A special thank to Dr. Nothias from Jussieu (Paris) and A. Paye for their precious advises on Schwann cell primary cultures and cytokine arrays.

\section{REFERENCES}

Anton ES, Weskamp G, Reichardt LF, Matthew WD 1994. Nerve growth factor and its low-affinity receptor promote Schwann cell migration. Proc Natl Acad Sci USA 91:2795-2799.

Autiero M, Luttun A, Tjwa M, Carmeliet P. 2003a. Placental growth factor and its receptor, vascular endothelial growth factor receptor-1: Novel targets for stimulation of ischemic tissue revascularization and inhibition of angiogenic and inflammatory disorders. J Thromb Haemost 1:1356-1370.

Autiero M, Waltenberger J, Communni D, Kranz A, Moons L, Lambrechts D, Kroll J, Plaisance S, De Mol M, Bono F, Kliche S, Fellbrich G, Ballmer-Hofer K, Maglione D, Mayr-Beyrle U, Dewerchin M, Dombrowski S, Stanimirovic D, Van Hummelen P, Dehio C, Hicklin DJ, Persico G, Herbert JM, Communi D, Shibuya M, Collen D, Conway EM, Carmeliet P. 2003b. Role of PlGF in the intra- and inter-molecular cross talk between the VEGF receptors Flt1 and Flk1. Nat Med 9:936-943.

Bae DG, Kim TD, Li G, Yoon WH, Chae CB. 2005. Anti-flt1 peptide, a vascular endothelial growth factor receptor 1-specific hexapeptide, inhibits tumor growth and metastasis. Clin Cancer Res 11:26512661.

Bannerman P, Ara J, Hahn A, Hong L, Mc Cauley E, Friesen K, Pleasure D. 2008. Peripheral nerve regeneration is delayed in neuropilin 2-deficient mice. J Neurosci Res 86:3163-3169.

Barrette B, Hébert MA, Filali M, Lafortune K, Vallières N, Gowing G, Julien JP, Lacroix S. 2008. Requirement of myeloid cells for axon regeneration. J Neurosci 28:9363-9376.

Beck H, Acker T, Puschel AW, Fujisawa H, Carmeliet P, Plate KH. 2002. Cell type-specific expression of neuropilins in an MCA-occlusion model in mice suggests a potential role in post-ischemic brain remodelling. J Neuropathol Exp Neurol 61:339-350.

Bolin LM, Verity AN, Silver JE, Shooter EM, Abrams JS. 1995. Interleukin-6 production by Schwann cells and induction in sciatic nerve injury. J Neurochem 64:850-858.

Borsani E, Albertini R, Labanca M, Lonati C, Rezzani R, Rodella LF. 2010. Peripheral purinergic receptor modulation influences the trigeminal ganglia nitroxodergic system in an experimental murine model of inflammatory orofacial pain. J Neurosci Res 88:2715-2726.

Bottomley MJ, Webb NJ, Watson CJ, Holt L, Bukhari M, Denton J, Freemont AJ, Brenchley PE. 2000. Placenta growth factor (PlGF) induces vascular endothelial growth factor (VEGF) secretion from mononuclear cells and is co-expressed with VEGF in synovial fluid. Clin Exp Immunol 119:182-188.

Bouquet C, Ravaille-Veron M, Propst F, Nothias F. 2007. MAP1B coordinates microtubule and actin filament remodeling in adult mouse Schwann cell tips and DRG neuron growth cones. Mol Cell Neurosci 36:235-247.

Carmeliet P, Moons L, Luttun A, Vincneti V, Compernolle V, De Mol M, Wu Y, Bono F, Devy L, Beck H, Scholz D, Acker T, DiPalma T, Dewerchin M, Noel A, Stalmans I, Barra A, Blacher S, Vandendriessche T, Ponten A, Eriksson U, Plate KH, Foidart JM, Schaper W, CharnockJones DS, Hicklin DJ, Herbert JM, Collen D, Persico MG. 2001. Synergism between vascular endothelial growth factor and placental growth factor contributes to angogenesis and plasma extravasion in pathological conditions. Nat Med 7:575-583.

Chattopadhyay S, Shubayev V. 2009. MMP-9 controls Schwann cell proliferation and phenotypic remodelling via IGF-1 and ErbB receptormediated activation of MEK/ERK pathway. GLIA 57:1316-1325.

Chen Y, Li X, Tian L, Lui VC, Dallman MJ, Lamb JR, Tam PK. 2007. Inhibition of sonic hedgehog signaling reduces chronic rejection and 
prolongs allograft survival in a rat orthotopic small bowel transplantation model. Transplantation 83:1351-1357.

Clauss M, Weich H, Breier G, Knies U, Röckl W, Waltenberger J, Risau W. 1996. The vascular growth factor receptor Flt-1 mediates biological activities: Implications for a functional role of placenta growth factor in monocyte activation and chemotaxis. J Biol Chem 27:1762917634

Cramer M, Nagy I, Murphy BJ, Gassman M, Hottiger MO, Georgiev O, Schaffner W. 2005. NF-kB contributes to transcription of placental growth factor and interacts with metal responsive transcription factor-1 in hypoxic human cells. Biol Chem 386:865-872.

D'Antonio M, Droggiti A, Feltri ML, Roes J, Wrabetz L, Mirsky R, Jessen KR. 2006. TGFbeta type II receptor signaling controls Schwann cell death and proliferation in developing nerves. J Neurosci 26:8417-8427.

De Falco S, Gigante B, Persico MG. 2002. Structure and function of placental growth factor. Trends Cardiovasc Med 12:241-246.

De Girolamo LA, Billett EE, Hargreaves AJ. 2000. Effects of 1-methyl4-phenyl-1,2,3,6-tetrahydropyridine on differentiating mouse N2a neuroblastoma cells. J Neurochem 75:133-140.

DiPalma T, Tucci M, Russo G, Maglione D, Lago CT, Romano A, Saccone S, Della Valle G, De Gregorio L, Dragani TA, Viglietto G, Persico MG. 1996. The placenta growth factor gene of the mouse. Mamm Genome 7:6-12

Dray C, Rougon G, Debarbieux F. 2009. Quantitative analysis by in vivo imaging of the dynamics of vascular and axonal networks in injured mouse spinal cord. Proc Natl Acad Sci USA 106:94599464.

Failla CM, Odorisio T, Cianfarani F, Schietroma C, Puddu P, Zambruno G. 2000. Placenta growth factor is induced in human keratinocytes during wound healing. J Invest Dermatol 115:388-395.

Fu ES, Zhang YP, Sagen J, Candiotti KA, Morton PD, Liebl DJ, Bethea JR, Brambilla R. 2010. Transgenic inhibition of glial NF-kappa B reduces pain behavior and inflammation after peripheral nerve injury. Pain 148:509-518.

Funakoshi H, Frisén J, Barbany G, Timmusk T, Zachrisson O. 1993. Differential expression of mRNAs for neurotrophins and their receptors after axotomy of sciatic nerve. J Cell Biol 123:455-465.

George LT, Myckatyn TM, Jensen JN, Hunter DA, Mackinnon SE. 2003. Functional recovery and histomorphometric assessment following tibial nerve injury in the mouse. J Reconstr Microsurg 19:41-48.

Giraud SN, Caron CM, Pham-Dinh D, Kitabgi P, Nicot AB. 2010. Estradiol inhibits ongoing autoimmune neuroinflammation and NF k kappa)B-dependent CCL2 expression in reactive astrocytes. Proc Natl Acad Sci USA 107:8416-8421.

Gould VE, Moll R, Moll I, Lee I, Schwechheimer K, Franke WW. 1986. The intermediate filament complement of the spectrum of nerve sheath neoplasms. Lab Invest 55:463-474.

Green CJ, Lichtlen P, Huynh NT, Yanovsky M, Laderoute KR, Schaffner W, Murphy BJ. 2001. Placenta growth factor gene expression is induced by hypoxia in fibroblasts: A central role for metal transcription factor-1. Cancer Res 61:2696-703.

Grove M, Plumb M. 1993. C/EBP, NF-kappa B, and c-Ets family members and transcriptional regulation of the cell-specific and inducible macrophage inflammatory protein 1 alpha immediate-early gene. Mol Cell Biol 13:5276-5289.

Haddad O, Chotard-Ghodsnia R, Verdier C, Duperray A. 2010. Tumor cell/endothelial cell tight contact upregulates endothelial adhesion molecule expression mediated by NFkappaB: Differential role of the shear stress. Exp Cell Res. 316:615-626.

Hattori K, Heissig B, Wu Y, Dias S, Tejada R, Ferris B, Hicklin DJ, Zhu Z, Bohlen P, Witte L, Hendrikx J, Hackett NR, Crystal RG, Moore MA, Werb Z, Lyden D, Rafii S. 2002. Placental growth factor reconstitutes hematopoiesis by recruiting VEGFR1 $(+)$ stem cells from bone marrow microenvironment. Nat Med 8:841-849.

Hnia K, Gayraud J, Hugon G, Ramonatxo M, De La Porte S, Matecki S, Mornet D. 2008. L-arginine decreases inflammation and modulates the nuclear factor-kappaB/matrix metalloproteinase cascade in $\mathrm{mdx}$ muscle fibers. Am J Pathol 172:1509-1519.

Hobson MI, Green CJ, Terenghi G. 2000. VEGF enhances intraneural angiogenesis and improves nerve regeneration after axotomy. J Anat 197:591-605.

Höke A, Sun HS, Gordon T, Zochodne DW. 2001. Do denervated peripheral nerve trunks become ischemic? The impact of chronic denervation on vasa nervorum. Exp Neurol 172:398-406.

Hollborn M, Tenckhoff S, Seifert M, Köhler S, Wiedemann P, Bringmann A, Kohen L, 2006. Human retinal epithelium produces and responds to placenta growth factor. Graefes Arch Clin Exp Ophthalmol 244:732-741.

Krum JM, Mani N, Rosenstein JM. 2008. Roles of the endogenous VEGF receptors flt-1 and flk-1 in astroglial and vascular remodeling after brain injury. Exp Neurol 212:108-117.
Kwon YK, Bhattacharyya A, Alberta JA, Giannobile WV, Cheon K, Stiles CD, Pomeroy SL. 1997. Activation of ErbB2 during Wallerian degeneration of sciatic nerve. J Neurosci 17:8293-8299.

Lauffenburger DA, Horwitz ,AF. 1996. Cell Migration: A physically integrated molecular process. Cell 84:359-369.

Lawson LJ, Frost L, Risbridger J, Fearn ,S, Perry VH. 1994. Quantification of the mononuclear phagocyte response to Wallerian degeneration of the optic nerve. J Neurocytol 23:729-744.

Ledeboer A, Gamanos M, Lai W, Martin D, Maier SF, Watkins LR, Quan N. 2005. Involvement of spinal cord nuclear factor kappaB activation in rat models of proinflammatory cytokine-mediated pain facilitation. Eur J Neurosci 22:1977-1986.

Leonardi A, Chariot A, Claudio E, Cunningham K, Siebenlist U. 2000. CIKS, a connection to Ikappa B kinase and stress-activated protein kinase. Proc Natl Acad Sci USA 97:10494-10499.

Li X, Gonias SL, Campana WM. 2005. Schwann cells express erythropoietin receptor and represent a major target for Epo in peripheral nerve injury. GLIA 51:254-265.

Li B, Sharpe EE, Maupin AB, Teleron AA, Pyle AL, Carmeliet P, Young PP. 2006. VEGF and PlGF promote adult vasculogenesis by enhancing EPC recruitment and vessel formation at the site of tumor neovascularization. FASEB J 20:1495-1497.

Liu H, Honmou O, Harada K, Nakamura K, Houkin K, Hamada H, Kocsis JD. 2006. Neuroprotection by PlGF gene-modified human mesenchymal stem cells after cerebral ischaemia. Brain 129:2734-2745.

Luttun A, Tjwa M, Moons L, Wu Y, Angelillo-Scherrer A, Liao F, Nagy JA, Hooper A, Priller J, De Klerck B, Compernolle V, Daci E, Bohlen P, Dewerchin M, Herbert JM, Fava R, Matthys P, Carmeliet G, Collen D, Dvorak HF, Hicklin DJ, Carmeliet P. 2002. Revascularization of ischemic tissues by PIGF treatment, and inhibition of tumor angiogenesis, arthritis and atherosclerosis by anti-Flt1. Nat Med 8:831840.

Maglione D, Guerriero V, Viglietto G, Delli Bovi P, Persico MG. 1991. Isolation of a human placenta cDNA coding for a protein related to the vascular permeability factor. Proc Natl Acad Sci USA 88:92679271.

Mani N, Khaibullina A, Krum JM, Rosenstein JM. 2005. Astrocyte growth effects of vascular endothelial growth factor (VEGF) application to perinatal neocortical explants: Receptor mediation and signal transduction pathways. Exp Neurol 192:394-406.

Mani N, Khaibullina A, Krum JM, Rosenstein JM. 2010. Vascular endothelial growth factor enhances migration of astroglial cells in subventricular zone neurosphere cultures. J Neurosci Res 88:248-257.

Mantuano E, Inoue G, Li X, Takahashi K, Gaultier A, Gonias SL, Campana ,WM. 2008. The hemopexin domain of matrix metalloproteinase-9 activates cell signaling and promotes migration of schwann cells by binding to low-density lipoprotein receptor-related protein. J Neurosci 28:11571-11582.

Moynagh PN, Williams DC, O'Neill LA. 1994. Activation of NF-kappa B and induction of vascular cell adhesion molecule- 1 and intracellular adhesion molecule-1 expression in human glial cells by IL-1. Modulation by antioxidants. J Immunol 153:2681-2690.

Ogata T, Yamamoto S, Nakamura K, Tanaka ,S. 2006. Signaling axis in schwann cell proliferation and differentiation. Mol Neurobiol 33:51-62.

Perrin FE, Lacroix S, Avilès-Trigueros M, David S. 2005. Involvement of monocyte chemoattractant protein-1, macrophage inflammatory protein- $1 \alpha$ and interleukin-1 $\beta$ in Wallerian degeneration. Brain 128:854-66.

Perry VH, Brown MC, Gordon S. 1987. The macrophage response to central and peripheral nerve injury. A possible role for macrophages in regeneration. J Exp Med 165:1218-1223.

Persico MG, Vincenti V, Di Palma T. 1999. Structure, expression and receptor-binding properties of placenta growth factor (PlGF). Curr Top Microbiol Immunol 237:31-40.

Perelman N, Selvaraj SK, Batra S, Luck LR, Erdreich-Epstein A Coates TD, Kalra VK, Malik P. 2003. Placenta growth factor activates monocytes and correlates with sickle cell disease severity. Blood 102:1506-1514

Rhee JW, Lee KW, Kim D, Lee Y, Jeon OH, Kwon HJ, Kim DS. 2007. NF-kappaB-dependent regulation of matrix metalloproteinase-9 gene expression by lipopolysaccharide in a macrophage cell line RAW 264.7. J Biochem Mol Biol 40:88-94.

Ribatti D. 2008. The discovery of the placental growth factor and its role in angiogenesis: A historical review. Angiogenesis 11:215-221.

Rogister B, Delrée P, Leprince P, Martin D, Sadzot C, Malgrange B, Munaut C, Rigo JM, Lefebvre PP, Octave J-N, Schoenen J, Moonen G. 1993. Transforming growth factor $\beta$ as a neuronoglial signal during peripheral nervous system response to injury. J Neurosci Res 34:32-43.

Runyan SA, Phelps PE. 2009. Mouse olfactory ensheathing glia enhance axon outgrowth on a myelin substrate in vitro. Exp Neurol 216:95-104. 
Scarlato M, Ara J, Bannerman P, Scherer S, Pleasure D. 2003. Induction of neuroplins-1 and -2 and their ligands, Sema3A, Sema3F, and VEGF, during Wallerian degeneration in the peripheral nervous system. Exp Neurol 183:489-498.

Schratzberger P, Schratzberger G, Silver M, Curry C, Kearney M, Magner M, Alroy J, Adelman LS, Weinberg DH, Ropper AH, Isner JM. 2000. Favorable effect of VEGF gene transfer on ischemic peripheral neuropathy. Nat Med 6:405-413.

Selvaraj SK, Giri RK, Perelman N, Johnson C, Malik P, Kalra VK. 2003. Mechanism of monocyte activation and expression of proinflammatory cytochemokines by placenta growth factor. Blood 102:15151524.

Shamash S, Reichert F, Rotshenker S. 2002. The cytokine network of Wallerian degeneration: Tumor necrosis factor- $\alpha$, interleukin- $1 \alpha$ and interleukin-1ß. J Neurosci 22:3052-3060.

Siebert H, Sachse A, Kuziel WA, Maeda N, Brück W. 2000. The chemokine receptor CCR2 is involved in macrophage recruitment to the injured peripheral nervous system. J Neuroimmunol 110:177-185.

Slobodov U, Reichert F, Mirski R, Rotshenker S. 2001. Distinct inflammatory stimuli induce different patterns of myelin phagocytosis and degradation in recruited macrophages. Exp Neurol 167:401-409.

Springer T, Galfré G, Secher DS, Milstein C. 1979. Mac-1: A macrophage differentiation antigen identified by monoclonal antibody. Eur J Immunol 9:301-306.

Stoll G, Griffin JW, Li CY, Trapp BD. 1989. Wallerian degeneration in the peripheral nervous system: Participation of both Schwann cells and macrophages in myelin degradation. J Neurocytol 18:671-683.

Subang MC, Richardson PM. 2001. Influence of injury and cytokines on synthesis of monocyte chemoattractant protein-1 mRNA in peripheral nervous tissue. Eur J Neurosci 13:521-528.

Takeda Y, Uemura S, Iwama H, Imagawa K, Nishida T, Onoue K, Takemoto Y, Soeda T, Okayama S, Somekawa S, Ishigami K, Takaoka M, Kawata H, Kubo A, Horii M, Nakajima T, Saito Y. 2009. Treatment with recombinant placental growth factor (PlGF) enhances both angiogenesis and arteriogenesis and improves survival after myocardial infarction. Circ J 73:1674-1682.

Taskinen HS, Röyttä M. 2000. Increased expression of chemokines (MCP-1, MIP-1alpha, RANTES) after peripheral nerve transection. J Peripher Nerv Syst 5:75-81.

Taniuchi M, Clark HB, Schweitzer JB, Johnson EM. 1988. Expression of Nerve growth factor receptors by Schwann cells of axotomized peripheral nerves: Ultrastructural location, suppression by axonal contact, and binding properties. J Neurosci 8:664-681.

Taylor AP, Goldenberg DM. 2007. Role of placenta growth factor in malignancy and evidence that an antagonistic PlGF/Flt-1 peptide inhibits the growth and metastasis of human breast cancer xenografts. Mol Cancer Ther 6:524-531;

Toews A, Barrett C, Morell P. 1998. Monocyte chemoattractant protein 1 is responsible for macrophage recruitment following injury to sciatic nerve. J Neurosci Res 53:260-267.

Tofaris G, Patterson PH, Jessen KR, Mirsky R. 2002. Denervated Schwann cells attract macrophages by secretion of leukemia inhibitory factor (LIF) and monocyte chemoattractant protein-1 in process regulated by interleukin-6 and LIF. J Neurosci 22:6696-6703.

Vallabhapurapu S, Karin M. 2009. Regulation and function of NF-kappaB transcription factors in the immune system. Annu Rev Immunol 27:693-733.

Vargas ME, Barres BA. 2007. Why is Wallerian degeneration in the CNS so slow? Annu Rev Neurosci 30:153-179.

Waller A. 1850. Experiments on the section of the glossopharyngeal and hypoglossal nerves of the frog, and observations of the alterations produced thereby in the structure of their primitive fibres. Philos Trans R Soc Lond 140:423-429.

Yin X, Wright J, Wall T, Grammas P. 2010. Brain endothelial cells synthesize neurotoxic thrombin in Alzheimer's disease. Am J Pathol 176:1600-1606. 